Cornell University Law School Scholarship@Cornell Law: A Digital Repository

Winter 2016

\title{
Instrumentalizing the Expressive: Transplanting Sentencing Circles into the Canadian Criminal Trial
}

Toby S. Goldbach

CornellLaw School,tsg36@cornell.edu

Follow this and additional works at: http://scholarship.law.cornell.edu/facpub

Part of the Criminal Procedure Commons, and the Indian and Aboriginal Law Commons

\section{Recommended Citation}

Toby S. Goldbach, "Instrumentalizing the Expressive: Transplanting Sentencing Circles into the Canadian Criminal Trial," 25

Transnational Law \& Contemporary Problems (2015)

This Article is brought to you for free and open access by the Faculty Scholarship at Scholarship@Cornell Law: A Digital Repository. It has been accepted for inclusion in Cornell Law Faculty Publications by an authorized administrator of Scholarship@Cornell Law: A Digital Repository. For more information, please contact jmp8@cornell.edu. 


\title{
Instrumentalizing the Expressive: Transplanting Sentencing Circles into the Canadian Criminal Trial
}

\author{
Toby S. Goldbach*
}

\begin{abstract}
This Article examines reforms to criminal sentencing procedures in Cunudu, foucising un Aboriginal healing circles, which were incorporated as "sentencing circles" into the criminal trial. Using the lens of comparative law and legal transplants, this Article recounts the period of sentencing reform in Canada in the 1990s, when scholars, practitioners, and activists inquircd into Aboriginal confrontation with the criminal justice system by comparing EuroCanadian and Aboriginal justice values and principles. As a way to bridge the gap betwcen vastly differing worldvicws and approaches to justice, judges and Aboriginal justice advocates transplanted sentencing circles into the sentencing phase of the criminal trial. This Article presents original data compiled from a review of all published decisions in Canada that mention the term sentencing circle. It rcvicws judicial treatment of requcets for sentencing circles, and tracks sentencing decisions oncc a circle was held. Additionally, this Article uses sentencing circles as a point of entry into conversations about legal instrumentalism in law reform and legal transplants. It argues that the progress of these reforms points to larger qucstions about culture and what it currently means to use law as a tool for social change.
\end{abstract}

- Toby S. Goldbach is an Adjunct Professor of Law and Postdoctoral Associate in the Graduate Legal Studies Program at Cornell University Law School. It is with heartfelt gratitude that I thank Aziz Rana, Valerie Hans, Annelise Riles, and Mitchel Lasser for their guidance in conducting the regearch and formulating the argumente for this Article. I am indobtod to thom for their insights and ideas. 


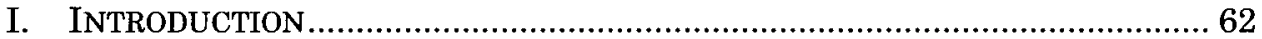

II. Comparative CRIMINAL LAW ............................................................ 72

A. Justice Studies 1967-1995 ......................................................... 72

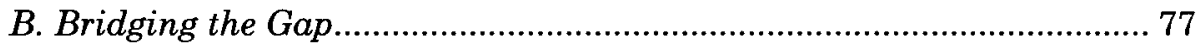

III. SENTENCING CIRCLE OUTCOMES.............................................................. 82

A. Sentencing Circles in the Criminal Trial........................................... 82

B. Requests for Sentencing Circles............................................................. 84

C. Sentencing Circle Recommendations ..................................................... 88

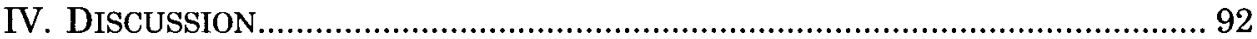

A. Debates in Comparative Law............................................................ 92

B. Objectification of Legal Knowledge .......................................................... 95

C. Introducing Legal Techniques................................................................. 97

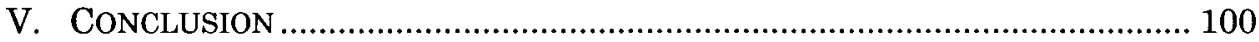

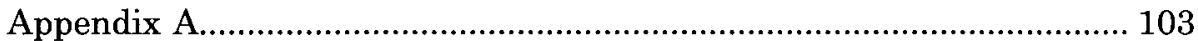

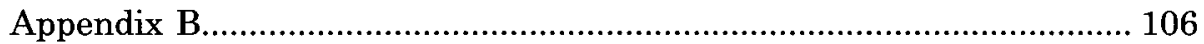

\section{INTRODUCTION}

Today's legal environment is one of creation, adaptation, and change. ${ }^{1}$ Whether in the pursuit of economic development, ${ }^{2}$ democratization, ${ }^{3}$ or

1 Sce John H. Merryman, Comparative Law and Social Change: On the Origins, Slyle, Declire and Revival of the Law and Development Movement, 25 AM. J. CoMP. L. 457, 457 (1977); Harold Hongju Koh, Transnational Legal Process, 75 NEB. L. REV. 181, 184, 205 (1996) ("Once nations begin to interact, a complex process occurs, whereby international legal norms seep into, are intornalized, and bocomo embedded in domeotic legal and political processes."); Tcrence C. Halliday, Architects of the Statc: Intcrnational Financial Institutions and the Reconstruction of States in East Asia, 37(2) L. \& Soc. INQUIRY 265, 266 (2012); Gregory Shaffer, Transnational Legal Process and State Change, 37 L. \& Soc. INQUIRY 229, 229 (2012); Terence C. Halliday, Rocurcivity of Global Normmakins: A Sociolegal Azenda, 5 ANr. REv. L. \& Soc. SCI. 263 (2009). But see Robert A. Kagan, Globalization and Legal Change: The "Americanization" of Europeun Law?, 1 REG. \& GOVERNANCE 99, 100 (2007) (challenging the suggestion that law in Western Europe is converging "with the American 'way of law,' particularly at the level of European nation-states, whose domestic legal systems and institutions still bulk large in the lives of individuals, business firms, and other organizations.").

${ }^{2}$ See, e.g., Ronald J. Daniels et al., The Legacy of Empire: The Common Law Inheritance and Commitments to Legality in Former British Colonies, 59 AM. J. CoMP. L. 111 (2011) (reviewing the literature on the relationship between legal transplants and economic developinent); Rafacl La Porta et al., The Economic Conecquences of Logal Origine, 16 J. ECON. LITERuTURE 285, 302, 324-25 (2008) (describing the reasons for legal transplants and examining the economic effects of legal origins, in particular the effect of common law legal systems on per capita income, investor protection, and financial development); see generally MichaEL J. TREBILCOCK \& RONALD J. Daniels, Rule of Law Reform and Development: Charting the Fragile Path of Progress $1-12(2008)$. 
political or social harmonization, ${ }^{4}$ identifying best practices $^{5}$ and transporting them elsewhere has become common-fare. Scholars who focus on "legal transplants" 6 tend to address two main sets of questions: first, how

${ }^{3}$ See, e.g., Kim Seong-Hyun, The Democratization and Internationalization of the Korean Legal Field, in LAWYERS AND THE RULE OF LAW IN AN ERA OF Globalization 217, 229-35 (Yves Dezalay \& Bryant G. Garth eds., 2011); Hiroshi Fukurai, Japan's Quasi-Jury and Grand Jury Systems as Deliberative Agents of Social Change: De-Colonial Strategies and Deliberative Participatory Democracy, 86 CHI.-KENT. L. REV. 789, 791 (2011) (arguing that the introduction of the quasi-jury and grand jury in Japan brought citizen oversight of the politioally elite - who were formerly considercd political "untouchableø"); Zachary Corcy \& Valerie P. Hang, Japan's New Lay Judge System: Deliberative Democracy in Action?, 12 AsIAN-PAC. L. \& POL'Y J. 72,89 (2010) (considering the potential of the new lay judge system in Japan to generate "legitimizing and civic engagement effects").

${ }^{4}$ See, e.g., Mads Andenas et al., Towards a Theory of Harmonisation, in THEORY AND PRACTICE of HARMONISATION 572, 573 (Mads Andenas \& Camilla Baasch Andersen eds., 2011) ("Harmonisation has been an important feature of modern legal systems . . . . For example, harmonization has bccn a core instrument of the European Union and Council of Europe; whilot at the international global level, there has been a long and established tradition of harmonisation of commercial law ...."); see generally John H. Merryman, On the Convergence (and Divergence) of the Civil Law and the Common Law, 17 STAN. J. INT'L L. 357 (1981) (outlining the political and cultural factors that both promote convergenoe of legal systoms and provide a force for decontralization); but see Rcinhard Zimmermann, Civil Code and Civil Law: The "Europeanization" of Private Law Within the European Community and the Re-Emergence of a European Legal Science, 1 CoLUM. J. EUR. L. 63, 73, 77-78 (1994) (discussing the implementation of directives. which allow national governments to choose tho form and mothod of compliance-as a mechanism for harmonization and detailing the negative consequences of using dircetives, such as increased fragmentation as a result of having two sots of rulos, or logal ossification as a result of the difficult process in generating initial agreement on the directive).

'David Kennedy, The "Rule of Law," Political Choices, and Development Common Sense, in TIIE New Law and Economic Development: A Critical Appraisal 95, 155 (David M. Trubek \& Alvaro Santos eds., 2006) (discussing devclopment professionale' turn away from oconomic analysis after the curreney crisis of the $1900 \mathrm{~s}$ to the identification of "boet practices" in economic development and performance); Katharina Pistor, The Standardization of Law and Its Effoct on Developing Economies, 50 AM. J. CoMr. L. 97, 97 (2002) (diocuseing the oxpoctation that adopting "best practices" and incorporating legal standards into conventions and treaties will have the "doublc bencfit of reducing transaction costo for tranonational investors and incroasing tho quality of legal institutions" in developing eountries); see also Jonathan Hill, Comparative Law, Law Reform and Legal Theory, 9 OXFORD J. LEGAL STUD. 101 (1989) (discussing the approach of "bctter aolution" comparative law scholara, who advocate for objectivo ovaluation of the various solutions provided by the world's legal aystems, and challenging the premice that thero can bo objectivity in identifying best practices).

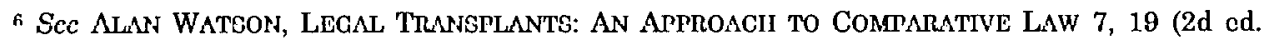
1003) (arguing that comparative law is predominantly the study of a hiotory of legal exchangos between legal systems, which consists of borrowing and modifying legal rules, and thus comparative law methodology should focus on legal transplants-the "borrowing and transmissibility of rules from one society or system to another" for the purpose of legal development); Daniel Berkowits et al, Economic Development, Legality; and the Transplant Effect, 47 EUR. ECON. REV. 165, 174 (2003) (explaining the meaning of a legal transplant could be undcrstood as follows: "[w]hen a transplant country applics a rule that it has tranoplanted from an origin, it is effectively applying a rule to its own local circumstances that was developed in a foreign socioeconomic order"); THE COMMON CORE OF EUROPEAN PRIVATE LAW (Mauro Bussani \& Ugo Mattei cds., 2003); Michele Graziadei, Comparative Law as the Study of Transplants and Receptions, in The Oxfond Handbook of Comparative LAW, 141-71 (Mathias Reimann \& 
legal rules or institutions travel, ${ }^{7}$ and second, how foreign laws interact with domestic legal systems. ${ }^{8}$ Scholars generally do not contest that transplanted legal institutions have the potential to solve socio-legal problems. Transplanting legal institutions is a matter "of usefulness and need. No one bothers to fetch a thing from afar when he has one as good or better at home. ..."9

Unfortunately, scholars have not examined institutions that are transplanted, not as a result of their usefulness, but rather because of their cultural and symbolic import. ${ }^{10}$ Are the problems raised by using legal transplants to represent cultural and humanistic goals different from other cases where there is a transplant effect?

This Article discusses reforms to Canadian criminal sentencing procedures and the incorporation of Aboriginal methods into the criminal trial. In particular, this Article presents the transplanted "sentencing circle" 11 as an example of how legal scholars' and practitioners' views regarding legal instrumentalism ${ }^{12}$ might be changing. This Article claims

Reinhard Zimmermann eds., 2006) (citing three causes for the movement of law: power, prestige, and inotitutional change aimed at improving economic performance).

${ }^{7}$ See, e.g., Ron Harris \& Michael Crystal, Some Reflections on the Transplantation of British Company Law in Post-Ottoman Palestine, 10 THEORETICAL INQUIRY L. 561 (2009) (examining company law transplante in Paleotine in the early 20th Century and arguing that lawyers, legal acadomics, and colonial logislatore influeneed the cxportation of English company law to countrios in the British Empire); see also WATSON, supra note 6.

8 See, e.g., Berkowitz et al., supra note 6, at 174 (arguing that a legal transplant "increases its own rocoptivity [in tho import country] by maling a significant adaptation of the forcign formal legal ordor to initial conditions, in particular to the preenisting formal and informal legal order. Changes in the transplanted rules or legal institutions indicate that the appropriatencas of these rules has been conoiderod and modifications were mado to take into account domestic legal practice or other initial conditions.") (emphasis in the original); see generally Máximo Langer, From Legal Transplants to Legal Translations: The Globalization of Plea Bargaining and the Americanization Thesis in Criminal Proceduro, 15 HARv. INT'L L. J. 1 (2001) (examining the wayo that local legal cultures in Germany, Italy, Argentina, and France interacted with the importation of American-style plea bargaining); Toby Goldbach et al., The Movement of U.S. Criminal and Administrative Law: Processes of Transplanting and Tranclating, 20 IND. J. GLOBAL LEGAL STUD. 141, 158-60, 164-67 (2013) (arguing that legal elites in Asia both imported and modified U.S. criminal procedures, such as plea bargaining and procedures for a jury trial for use in the criminal trial).

9 KONRAD ZWEIGERT \& HEIN KÖETZ, AN INTRODUCTION TO COMPARATIVE LAW 17 (Tony Weir trans., 3d ed. 1998).

10 See discussion infra Part IV. A.

11 I refer to the traditional Aboriginal procese and the process incorporated into the criminal trial by the following terms: "healing circle" and "sentencing circle" respectively. Some texts, government documonte, and cases use these terms interchangeably. While there is no one form of healing circle that covers all traditional processes, I try to keep the terms separate, in the very least to place an omphasis on the proceso of transplantation.

12 On the meaning of legal instrumentalism, see generally Karl N. Llewellyn, $A$ Realistic Jurisprudence-the Next Step, 30 COLUM. L. REV. 431, 452 (1930) ("It seems patent that only a 
that law reform goals have become more "expressive," 13 in that they include cultural and normative goals in addition to, or instead of, sociological goals. The effect is to "instrumentalize" 14 culture and normativity. ${ }^{15}$ In

gain in realism and effectiveness of thinling can como from congistontly (not oconsionally) regarding the official [logal] formulation as a tool, not as a thing of value in itsolf; as a means without meaning save in terms of its workings, and of meaning in its workings only whon thece last are compared with the results desired."); John Dewey, Iogical Method and Iaw, 10 CoRNFI.I. L.Q. 17, 23, 26 (1921) ("As matter of actual fact, we generally begin with some vague anticipation of a concluaion (or at lcast of alternative conclusions), and then we look around for principles and data which will substantiate it or which will enable us to chooes intolligontly betwoon rival conclusions. No lawyer ever thought out the case of a elient in terms of the syllogism. He begine with a conclusion which he intendo to reach, favorablc to his clicnt of courac, and then analyzes the facts of the gituation to find material out of which to construct a favorable statement of facto,

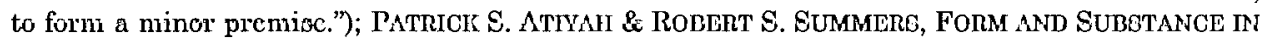
ANGLO-AMERICAN LAW: A COMPARATIVE STUDY OF LEGAL REASONING, LEGAL THEORY AND LEGAL IrSTTITUTIONG 93 (1987) ("ruleo are conceived eosentially as inotrumonto as means to sound goals ....."). On the place of legal instrumentalism in legal scholarship, see ROBERT S. SUMMERS, INSTRUMENTALISM AND AMERICAN LEGAL THEORY 31, 35, 60 (1982) (the most sustained and prominent belief about law in the last hundred years has been that law is a social instrument; social reality is malleable and can be altered "by humano for human purpoees in the course of solving problems"); BRLAN Z. TAMMNAHA, LAW AS A MEANS TO AN END: THREAT TO TIIE RULE OF LuW 118 (2006) ("Almost all of the major theoretical and ompirical perspectives toward law that circulate today . . . characterize law in fundamentally instrumental terms."); Mark Kelman, The Past and Future of Legal Scholarship, 33 J. LEGAL EDUC. 432, 433 (1983) ("The instinct of most law professors-again when discussing big concepts, like the nature of property i. is unqucotionably to be highly positivistic and instrumentalist"); Austin Sarat \& Susan Silbey, The Pull of the Policy Audience, $10 \mathrm{~L}$. \& POL'Y 97, 104 (1988) ("At the beginning of the 20th century, the modest reform efforte of legal realism advanced an instrumentalist concopt of law. In this, legal realiom reacted against then prevailing formalist conceptions of law and workcd to adapt legal thought to ... one in which the otate came to assume a much moro oxplicit role in steering society); see generally Bryant G. Garth \& Austin Sarat, Studying How Law Matters: An Introduction, in How DoEs LAW MATTER? (Bryant G. Garth \& Austin Sarat eds., 1998); Richard L. Abel, Law and Society: Project and Practice, 6 ANN. REV. L \& Soc. SCI. 1 (2010); Daphna Hacker, Law and Society Jurisprudence, 96 CoRNELL L. REv. 727, 742 (2011) (examining the place of legal instrumentalist thought and the "preoccupation" with "legal reforms aimed at achieving social goals" in the Law and Society movement in Israel). On the diatinction between "law as a tool" and legal toohniques, see Annelies Rilec, A Now Agenda for the Cultural Study of Law: Taking on the Technicalities, 53 BUFF. L. REV. 973, 975 (2005) [hereinafter Taking on the Technicalities] (arguing that both instrumentalist and cultural/humanistic studies of law ignore the technical dimensions of legal form: "To the instrumentalist . . . the tochnical detailo of doctrine are interesting only insofar as they are relevant to what lawyero sometimes term 'building a better mousetrap.' Thoy do not become the subject of any deeper or more critical inquiry."); and ooe genorally Alain Pottage, Law After Anthropology: Object and Technique in Roman Law, 31 THEORY, CULTURE \& SOC'Y 147 (2014).

${ }^{13}$ See Annelise Riles, Law as Object, in LAW \& EMPIRE IN THE PACIFIC: FiJl AND HAWAI'I, 187-212 (Sally Engle Merry \& Donald Brenneis eds., 2004) [hereinafter Law as Object].

14 Nlain Pottage, The Socio Legal Implications of the New Biotechnologics, 3 ANN. REV. L. \& Soc. SCI. 321, 324 (2007).

15 See generally JUTtA BRUNNEE \& STEPHEN J. TOOPE, LEGITIMACY AND LEGALITY IN INTERNATTONAL LAW: AN INTERACTIONAL ACCOUNT 33-55, 85 (2010) (providing an account of the role of procedural fairness values in international law and international relations: "Interactional law undercuts the ability of powerful actors to put forward utterly self eerving or perverse normative claims, because the claims will have to be measured against the eight criteria of 
transplanting Aboriginal justice methods into Euro-Canadian criminal trials, justice advocates intended to recognize Aboriginal peoples' rights in the administration of justice. ${ }^{16}$ This then poses the following questions: How do

legality, and will have to fit within shared understandings generated through inclusive participation of all social actors."). For the most obvious example of melding instrumental and normative goals as the rulo of law in Law and Development projects, sec Kennedy, supra note 5 , at 156-57 (providing an account of how human rights and the rule of law have been incorporated into the meaning of development); TREBILCOCK \& DANIELS, supra note 2, at 4 (2008) (examining the role of the rule of law in development: "the claim that the robustness of a country's commitment to the rulo of law is an important doterminant of its development trajectory resto upon both instrumental foundations and on intrinsic or dcontological foundations."). Another example is the proliferation of new jury and lay judge systems in Eastern Europc and East $\Lambda$ sia in support of democratic reforms. See Hiroshi Fukurai et al., The Resurgence of Lay Adjudicatory Systems in East Asia, 12 AsIAN-PAC. L. \& POL'Y J. i, iii (2010) (comparing the "wave" of legal roforms to introduco lay judges in East Asia to trial by jury in the 19th Century, which "bceamc an integral part of the emerging democratic societies in the U.S. and other nations on the European Continent"); Fukurai, supra note 3; Ryan Park, The Globalization of the Jury Trial: Lessons and Insights from Korea, 58 AM. J. CoMP. L. 525, 534-35, 546 (2010) (examining the connection between lay participation in judicial decision-making and "broader democratic governanoo," and rooounting the introduction of the jury trial as part of efforts to demoeratize Eactern Europe in the $1990 \mathrm{~s}$ and South Korea in the late 1090s and early 8000s); Richard 0. Lomport, The Intcrnationalization of Lay Legal Decision-Making: Jury Resurgence and Jury Research, 40 CORNELL INT'L L.J. 477, 479 (2007); NIKOLAI KOVALEV, CRIMINAL JUSTICE REFORM

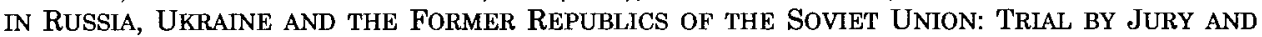
MIXED COURTS 2-3 (2010) (noting that many countries formerly part of the Soviet Union are introducing lay judge reformo; "transitioning" their criminal justice systems at the same timc as undertaking political and cconomic transitions to democracy and frec market cconomy). For morc traditional portrayalo of legal transplants as a conøequence of pressure, prestigc, or instrumcntal rationality, see generally Graziadei, supra note 6; La Porta et al., supra note 2; Ugo Mattei, Efficiency in Legal Trangplants: An Eccay in Comparative Law and Economics, 11 INT'L REv. L. \& ECON. 1, 16 (1994).

16 Ministry OF THE SOlicitor GENERAL, OTTAWA (ONTARIO), TASK FORCE ON ABORIGINAL PeOples In Federal Corrections, Final RePort 10-11 (1988); PaUl L.A.H. Chartrand, Royal Commission on Aboriginal Peoples, Bridging the Cultural Divide: A Report on Aboriginal People and CRIminal Justice IN CANAdA 3 (1996) [hereinafter BRIDGING THE CULTURAL DIVIDE] ("The right of Aboriginal self-government is argued to be a common law right in Canada, one that is protected by the Constitution. Aboriginal control over the substance and process of justice flowing from the Aboriginal right of self-government would permit the contemporary exprossion of Aboriginal concepta and proccsoes of justice."); ROYAL COMmISSIOr ON ABORIGINAL PEOPLES, 1 REPORT OF THE ROYAL COMMISSION ON ABORIGINAL PEOPLES 610, 679-81 (1996); John Giokas, Accommodating the Concerns of Aboriginal People Within the Existing Justice System, in ABORIGINAL PEOPLES AND THE JUSTICE SYSTEM 184, 184 (Royal Commission on Aboriginal Peoples eds., 1992) ("This paper has been written against the baolidrop of thio national and international drive of Aboriginal peoples for a greater degrec of control over their own affairs. The basic theme of this paper can be summarized in one word: omorgonce. A now order is emerging in Canada that will cover most important aspecta of the new rolationohip between Aboriginal and non Aboriginal Canadians . . . Juaticc administration is one of those areas."); Donald Clairmont, Alternative Justice Issues for Aboriginal Justice, $36 \mathrm{~J}$. LEGAL PLURALISM \& UNOFFICIAL L. 125, 125 (1996); see R. v. Morin (I.) (1995), 134 Sask. R. 120, para. 27 (Can. Sask. C.A.) ("The very purpose of sentencing circles seems to be to fashion centences that will differ in come mix or measure from those which the courts have up to now imposed in order to talke into account aboriginal culture and traditions, and in ordcr to permit and to tako into account direct community participation in both imposition and administration of 
we measure the impact, effects, or the extent of "translation" 17 in such cases? What is the effect of transplanting legal institutions that are intended to fulfill both sociological and corrective justice goals? What if, in addition to being an example of best practices, the legal transplant is also meant to signify a move toward repairing historical injustices?

In 1992, Justice Barry Stuart of the Yukon Territorial Court used an approach based on local First Nations' methods of dealing with crime. ${ }^{18}$ This was the first instance of adapting an Aboriginal healing circle for use in a Canadian criminal trial. ${ }^{19}$ Following Justice Stuart's example, other trial judges began to conduct sentencing circles on an ad hoc basis as part of the discretion they had in sentencing decisions. ${ }^{20}$ By the mid-1990s, judicial innovation, legislative reform, and bureaucratic efforts effectively "transplanted" Aboriginal healing circles into the criminal trial. Presently, sentencing circles contribute to the institutionalized landscape to such an extent that in April 2014 the Ministry of the Attorney General (Ontario) unveiled a new courthouse with rooms specifically designed for Aboriginal conferencing and ceremonies. ${ }^{21}$

Sentencing circles are a legal procedure in which "the community offers its input to the sentencing court." 22 During a sentencing circle, criminal justice participants and members of the community have an opportunity to speak about the crime in question and its impact on the community. ${ }^{23}$ The

the sentence."); sec also discussion of the Aboriginal Justiec Initiative and $\Lambda$ boriginal Justico Strategy infra Part II.B.

${ }^{17}$ Langer, supra note 8, at 13-14.

${ }_{18}$ This first sentencing circle took place in Mayo, Yukon in R. v. Moses, [1992] B.C.W.L.D. 1294 (Can. Y.K.T.C.), additional reasons provided in $R$. v. Moses, [1992] 71 C.C.C. (3d) 347 (Can. Y.K.T.C.) and were as a result of conoultationo betwoen the Kwanlin Dun First Nation and justice officials. The Church COUNCI ON Justice \& Corrections, SATISFYing Justice: A COMPENDIUM OF INTIATIVES, PROGRAMS AND Legislative MEASURES (1996); see also BRIDGING THE CUlTURAL DIVIDE, supra note 16, at 110.

${ }^{19}$ R. v. Nicholas (B.L.) (1996), 177 N.B.R. 2d 124 (Can. N.B.P.C.); BARRY STUART, BUILDING COMmunity Justice PARTNERShIPS: COMMUNity PEACEMAKING CIRCles 124 (1997), http://publications.gc.ca/collections/collection_2009/justice/J22-12-1997E.pdf.

${ }^{20}$ Heino Lilles, Circle Sentecing: Part of the Restorative Justice Continuum, INT'L INST. FoR Restorative Practices (Aug. 9, 2002), www.iirp.edu/article_detail.php?article_id=NDQ3. The common law authority for conducting sentencing circleo was found by Justice Sherstobitoff of the Saskatchewan Court of Appeal in R. v. Morin (I.) (1995), 134 Sask.R. 120 (Can. Sask. C.A.).

${ }^{21}$ Ministry of the ATtorney General, Aboriginal ConfERenCe SeTtlement Suite Final REPORT (2009); Thunder Bay Courthouse-Adamson Associates Architects, ARCHDAIIY, http://www.archdaily.com/511799/thunder-bay-courthouse-adamson-associates-architects/ (last visited Feb. 2, 2016).

22 R. v. Cooper (2010), 101 O.R. 3d 1 (Can. Ont. C.A.).

${ }^{23}$ Maureen Linker, Sentencing Circles and the Dilemma of Difference, 42 CRIM. L.Q. 116, 117 (1999) ('The judge's role is to oversee diseuscion and seck out answers to the following kindo of queations: What are the underlying causee of the crime? What impact has the crime had on the 
number of participants can vary from ten to fifty individuals. ${ }^{24}$ In sentencing circles, which may last several hours, participants often make sentencing recommendations. At the conclusion of a sentencing circle that the court holds as part of an adult criminal trial, the participants return the matter to the court for final submissions and judicial decision. The law does not require the judge to follow the sentencing circle's reccommendations. ${ }^{25}$ In many ways, though, sentencing circles represent an exception to the trend currently underway in common law countries to curtail lay participation in sentencing. ${ }^{26}$ Therefore, because sentencing circles involve significant community participation, it is important to analyze whether, and how, judges respond to sentencing circle recommendations in the final sentencing stage.

An additional goal of this Article is to identify and present a cultural turn in legal thinking, one in which the expressive genre of law (which generates and produces meaning) ${ }^{27}$ serves to mark and achieve other goals. This Article presents a story of legal pluralism, attempts at multiculturalism, Aboriginal law, and alternatives to criminal sentencing procedures. On a deeper level, however, it provides an account of legal instrumentalism and what it currently means to use law as a tool for social change.

In Canadian sentencing reform, through an exercise in comparative criminal law, ${ }^{28}$ scholars, practitioners, and activists made Aboriginal culture into an object of knowledge ${ }^{29}$ and then constructed expressions of Aboriginal culture as instruments of legal value. Government studies and legal reports compared Euro-Canadian and Aboriginal approaches to justice, and

victim, his or hor family, and the community? What are the details of all the potential sentenees. . ?"). See, e.g., R. v. Van Bibber, [2010] Y.K.T.C. 49 (Can.); R. v. MacKendrick, [2007] B.C.W.L.D. 6450 (Can. B.C.P.C.) (finding that the "unusual nature and number of victims in the Langley community who were adversely affected" by the crime made the usc of a sentencing circle even more poignant). But see Mary Crnkovich, A Sentencing Circle, 36 J. LEGAL PLURALISM \& UNOFFICIAL L. 159, 165 (1996) (describing a sentencing circle that took place in the Nanuvik rogion of Quobec where the community's role was unclear).

24 Lilles, supra note 20.

${ }^{25}$ R. v. Taylor (1995), 132 Sask. R. 221, para. 10 (Can. Sask. Q.B.) ("It must be remembered that the rocommondation of a circle is not binding on the sentencing judge."); sec also BRIDGIPJG TIIE CULTURAL DIVIDE, supra note 16, at 110, 113-14; infra note 41 and accompanying text. discussion infra note 41.

26 See Nancy J. King \& Rosevelt L. Noble, Felony Jury Sentencing in Practice: A Three-State Study, 57 VAND. L. REV. 885 (2004); Toby S. Goldbach \& Valerie P. Hans, Juries, Lay Judges, and Trials, in ENCYCLOPEDLA of CRIMTNOLOGY AND CRIMINAL JUSTICE (Gerben Bruinoma \& David Weisburd eds., 2014) (showing how in Canada, juries may give recommendations for parole in first and second degree murder trials; the law restricts lay participation to those circumetances, and jury rocommendations are not mandatory).

${ }^{27}$ Law as Object, supra note 13.

28 Markus D. Dubber, Criminal Law in Comparative Context, 56 J. Legal EduC. 433 (2006).

${ }^{29}$ Law as Object, supra note 13; see generally MARIANA VALVERDE, LAW'S DREAM OF A COMMON KNOWLEDGE (2003). 
connected sociological and political adversity with the need for justice reform. Advocates explicitly distinguished Aboriginal healing circles from official state procedures and then presented the former as an alternative dispute resolution process with equally legitimate jurisdictional claims. With that legal authority, culturally appropriate processes became an instrument that law reformers could use to address normative and sociological goals.

Though often thought of as progressive in its pragmatic approach to law, there is a sense that legal instrumentalism, "the hegemonic logic of means and ends," 30 risks destabilizing developments in its effort to deem everything up for instrumental grabs. Therefore, instrumentalizing the expressivefashioning constructed expressions of culture into an instrument for usemay present new and troubling implications for what it means to employ the law as a tool metaphor. Scholars, practitioners, and reformers should become more familiar with the ways that back and forth movement between the instrumental and the expressive present a moment of jeopardy for unmet expectations. In the very least, they should make use of the technical legal devices and knowledge practices to which legal intermediaries regularly appeal. ${ }^{31}$

This Article employs a mixed methodology; it looks at government, task force, and law reform commission reports, as well as all published decisions where sentencing circles were requested and/or used. Part II reviews more thoroughly the background and situates the reforms in comparative law literature in order to give context to the kinds of conversations that were going on about how to change criminal sentencing in Canada. Readers might react negatively towards Aboriginal law analyzed within the framework of comparative law and legal transplants. Clearly, the histories of colonial relations and confrontations with indigenous communities, marked by paternalism and overt efforts to suppress culture, preclude adopting the "apolitical" comparative law analysis. ${ }^{32}$ However, one of the underlying goals of

${ }^{30}$ Annelise Riles, Anthropology, Human Rights, and Legal Knowledge: Culture in the Iron Cage, 108 AM. ANTHROPOLOGIST 52, 60 (2006).

31 See, e.g., Taking on the Technicalities, supra note 12; see generally Alain Pottage, The Materiality of What?, 39 J.L. \& Soc'Y 167 (2012) [hereinafter The Materiality of What?].

32 See David Kennedy, New Approaches to Comparative Law: Comparativism and International Governance, 2 UTAII L. REV. 545, 554 (1997) (Comparative law "see[s] itself as preciscly not about polities or governanec, as existing rather in the roalm of history or thought, as an intollectual project of understanding between cultures whose similarities and difforonces are forogroundod."). In particular, legal anthropologists might be concerned that commissions and tasl foroes constructed an Aboriginal sentencing process. See, e.g., Martin Chanock, The Law Market: The Legal Encounter in British East and Central Africa, in EUROPEAN EXPANSION AND LAW (W. J. Mommsen \& J. A. de Moor eds., 1992); Marilyn Strathern, Discovering 'Social Control', 12 J. L. \& SoC'Y 111, 111 (1985); Peter Fitzpatrick, Traditionalism and Traditional Law, 28 J. AFR. L. 20 (1981). However, a solc focus on the expressive or meaning malking genre of law can overlook results of the second genre of law-making whore law is a thing in the world. See Law as Object, 
this Article is to present the example of transplanted Aboriginal methods as a means to disturb convenient encampments. By invoking the transplant metaphor and examining the types of questions comparative law scholars ask, ${ }^{33}$ this Article seeks to confront divisions between comparative law, ${ }^{34}$ legal pluralism, ${ }^{35}$ and law and development literature. ${ }^{36}$ Sitting at the intersection of those three disciplines, sentencing circles are uniquely positioned to prompt readers to consider assumptions about whose law is fit for transplanting and the kinds of questions that are asked in certain arcas of law.

Part II chronicles a period of intense government scrutiny into Aboriginal confrontation with the criminal justice system, the initial legislative and judicial reforms, the subsequent transplantation, and the institutionalization of sentencing circles into the criminal trial.

Part III adopts the typical comparative law and legal transplant approach, examining the process of transplantation and how sentencing circles fared once transplanted into the Euro-Canadian legal system. This Part presents a brief qualitative report of findings from all published Canadian decisions that dealt with sentencing circles, ranging from the first time a sentencing circle was held during a criminal trial in 1992 to decisions as recent as 2010.37 This Article analyzes the outcomes of requests to hold a

supra note 13 , at 190 . Put most simply, sentencing circles have been incorporated, transplanted, and used in the criminal trial. So, it still bears worth to investigate how this played out.

33 See Mitchel Lasser, The Question of Understanding, in COMPARATIVE LEGAL STUDIES: Traditions and Transitions 197, 197-239 (Pierre Legrand \& R. J. C. Munday eds., 2003).

is Each of those sub-disciplinos explores the movement of law and the interaction betwecn culture, local needs, and official (state) legal orders, but they tend to adhere to their own constituencies: Comparative Law to European and North American audiences. See, e.g., THE COMmon CORe of Europenn PRIVATE LAW, supra note 6; Pierre Legrand, The Impossibility of Legal Transplants, 4 MAASTRICHT J. EUR. \& COMP. L. 111 (1997); Mathias Reimann, The Progress and Failure of Comparative Law in the Second Half of the Twentieth Century, 50 AM. J. COMP. L. 671 (2002).

35 Legal Pluralism explores African or Western informal, customary, or religious legal orders as objects of study. See, e.g., MARTIN CHANOCK, LAW, CUSTOM, AND SOCIAL ORDER: THE COLONIAL EXPERIENCE IN MALAWI AND ZAMBIA (Jim Lance ed.,1998); Chanock, supra note 32; Fitzpatrick, supra noto 32; Strathern, supra notc 32; Sally Engle Mcrry, Lcgal Pluralism, 22 L. \& Soc'y REV. 869 (1988).

36 Law and development scholars examine developing states (as opposed to developing communities) in Latin America, Eastern Europe or North Africa. See, e.g., Pistor, supra note 5; Alvaro Santos, The World Bank's Uses of the "Rule of Law" Promise in Economic Development, in The NEW LAW AND Economic DeVElopment: A CRITICAL APPRAisal 253-300 (David Trubek \& Alvaro Santos eds., 2006); César Rodriguez-Garavito, Toward a Sociology of the Global Rule of Law Field: Neoliberalism, Neoconstitutionalisms, and the Contest Over Judicial Reform in Latin America, in LAWYERS AND THE RULE OF LAW IN AN ERA OF GLOBALIZATION 156-83 (Yves Dezalay \& Bryant G. Garth eds., 2011).

${ }^{37}$ I chose December 2010 as the date to end data collection to provide a clean cut off point. I was also able to ensure I could access all the reported cases for that period, in case there was any 
sentencing circle at the sentencing phase, as well as outcomes on sentencing after a sentencing circle was conducted. Part III proceeds within a framework of lay participation in law, ${ }^{3 R}$ arguing that the outcomes of incorporating these procedures should be judged against the kinds of goals that normally underlie lay and community participation in shaping sentences for convirter offenders. In this view, the ambiguous results become less important than the way those results were achieved.

The discussion in Part IV challenges legal intermediaries to address the "transplant effect." 39 It suggests that judges have tools that can be employed to assess and process sentencing circle recommendations. ${ }^{40}$ Lay participation in sentencing has been all but eliminated in many jurisdictions-including Canada-so the ultimate authority for sentencing defendants resides with the judge. ${ }^{41}$ Nevertheleso, this Article suggests that where lay participation and culture is instrumentalized, judges may need to employ the law's technical contributions. ${ }^{42}$ The suggestion to use formalities or technical legal approaches to distill Aboriginal procedures may seem odd. However, part of this Articles's is to query whether decoupling legal formalism from legal techniques ${ }^{43}$ might mediate the risks associated with instrumentalizing normative and expressive goals.

delay botwoen the decision and the reporting of tho caso. Admittodly, 2010 is an arbitrary out off joint, but, as there have not becn any significant changes to the Criminal Code or to the way sentencing circles are being conducted, I have no reason to believe that the conclusions that I will draw are in any way affected by this cut off point.

38 See Goldbach \& Hans, supra note 26.

${ }^{39}$ Berkowitz et al., supra note 6, at 167.

40 See infra Part IV.

41 Criminal Code, R.S.C. 1985 , c. C-46, s. 720 , s. 745 , c. 97 (1st Supp.), s. $155 ; 1995$ c. 22, s. 6; 2015 , c. 13, o. 23. Senteneing procecdingo are carried out by the court, ereept where a jury finds an accusod guilty of cooond dogroo murder, guilty of murder whore the accusod has a prior conviction for murder, or whoro tho accused was under the ago of sixtoon; in those cases, the

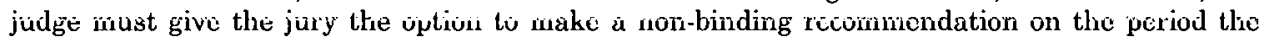
accused is requirod to servo before being eligible for release on parole. See Neil Vidmar, The Canadian Criminal Jury: Searching for a Middle Ground, 62 L. \& CONTEMP. PROBS. 141, 148 (1999); Goldbach \& Hans, supra note 26, at 2721.

42 Sec, o.g., Karon Knop, Ralf Michaolø \& Annolieo Rilos, From Multiculturalism to Tochnique: Feminism, Culture, and the Conflict of Laws Style, 64 STAN. L. REV. 589, 594-95 (2012); Law as Object, supra note 13, at 1026-27.

43 See ANNELise RILES, Collateral KNOWLEDGE: LEgal REASONING IN THE Global FtNancial MARKETS 70-71 (2011) [hereinafter COLLATERAL KNOWLEDGE] (arguing that an ethnography of legal crpertise must include a closo oxamination "of the skill and the art, the aesthotice and the bricolage, the satisfaction of rehearsing and perhaps innovating upon or adding to a set of moves and postures one has observed, apprenticed, debated with other initiates," which is distinguishable from legal formalism, "the view that legal form constrains politics"); see also VALVERDE, supra noto 29, at 28 (distinguishing botwoen oocio logal ccholarship; which cxamineo the ways that law, formally applied, reproduces forme of power relations, and the atudy of the "mechanisms" by which law produces or "constitutes" knowledge). 


\section{COMPARATIVE CRIMINAL LAW}

\section{A. Justice Studies 1967-1995}

The Canadian government transplanted Aboriginal healing circles into the Canadian criminal trial following a cross-national exercise that analyzed Aboriginal confrontation with the criminal justice system using a comparative law methodology. Starting from the position that the relationship between Aboriginal peoples and the criminal justice system needed to change, government sponsored inquires focused on the conflict between justice values and principles by comparing Aboriginal and EuroCanadian approaches to crime. ${ }^{44}$

Between 1967 and 1995, provincial and federal levels of government sponsored more than thirty justice studies ${ }^{45}$ regarding the causes and effects of systemic discrimination against Aboriginal people. ${ }^{46}$ For example, the Task Force on the Criminal Justice. System and its Impast on the Indian and Metis People of Alberta assigned former Chief Judge of the Provincial Court, Justice Allan Cawsey, a mandate "to complete a review of the criminal justice system in Alberta as it relates to Indian and Metis people." 47 The Alberta Task Force combined submissions from law organizations, researchers, and native groups with statistical data. Similarly, the Royal Commission on Aboriginal Peoples ("RCAP") heard testimony at public hearings, accepted submissions from organizations funded through an intervener participation program, sponsorcd rcscarch studics, and organizcd national "round tablcs" on Aboriginal issues, which brought together academics, practitioners, politicians, and community leaders. ${ }^{48}$

First, task forces, inquiries, and royal commissions sought to understand why and how the criminal justice system negatively affected Aboriginal

44 Individual scholare aleo took on the task of investigating the conflicto between juotice and

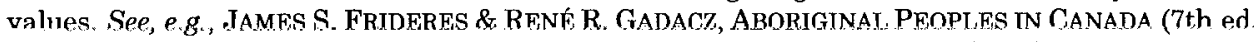
2004); RUPERT ROSS, DANCING WITH A GHOST: EXPLORING INDIAN REALITY (1992).

45 Dara Culhane, Justice and Healing: Aboriginal Pcoples in Canada, 6 J. HUM. JUsT. 110, 151 (1995).

4h In addition to the roports and commisoione oited in the text, seo Gov'T OF CANADA ET AL., REFleCting INDIAN CONCERNS AND VALUES IN THE JuSTICE System (1985); ChIEF Justice T.

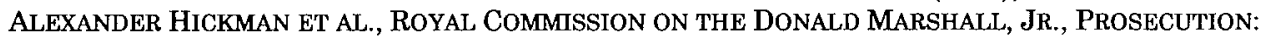
Digest of Findings aNd Recommendations (1989); Judge Patricia LinN, Fed'N of SASK INDIAN NATIONS ET AL., REPORT OF THE SASKATCHEWAN INDIAN JUSTICE REVIEW COMMITTEE (1992); TASK ForCE ON FEDERALLY SENTENCEd WoMEN, CREATING ChOICES: THE REPoRT OF THE TASK FORCE ON FEDERALLy SENTENCED WOMEN (1990).

47 Task Force on the CRIminal Justice System and ITS IMPaCt on the INDian and MEtis People of Alberta, Justice on TRIAL: Report of the TASK Force on the CRIMINAL Justice System AND ITS IMPACT ON THE INDIAN AND METIS PEOPLE OF ALBERTA, 1-1 (1991).

48 James S. Frideres, The Royal Commission on Aboriginal Peoples: The Route to SelfGovernment?, 16 CAN. J. NATIVE STUD. 247, 247-53 (1996). 
offenders. ${ }^{49}$ They examined feelings of alienation, as well as the disproportionate representation of Aboriginal offenders in provincial and federal prisons. ${ }^{50}$ For example, RCAP's comprehensive report found that, in Saskatchewan, a treaty Indian boy of sixteen had a 70 percent chance of serving a prison term by the age of twenty-five, while a non-Native Saskatchewan boy only had an 8 percent chance. ${ }^{51}$ Comparing populations with penal statistics also illustrated the extent of over-incarceration. ${ }^{52}$ In the

49 See, e.g., MINISTRY OF SOLICITOR GENERAL, OTTAWA (ONTARIO), supra note 16, at 23, 28; ALVIN Hamilton, A Feather, Not A GaVel: Working TOWARdS Aboriginal JUSTICE 49, 61 (2001) (describing the efforts of the Aboriginal justice inquiry in Manitoba to learn about structural impcdiments to juatice and the particular diocrimination in effect in Winnopog: " $\Lambda$ boriginal city residents ... described their personal experiences with police brutality; the courts' indifforonce and the oppression of bigotry and discrimination . . . ."); see also Daniel Kwochka, Aboriginal Injustice: Making Room for a Restorative Paradigm, 60 SASK. L. REV. 153, 154-55 (1996).

${ }^{50}$ MINISTRY OF SOlicitor GENERAL, OTTAWA (ONTARIO), supra note 16, at 5, 23; JAMES DUMONT, JUSTICE APD ADONIGINAL PEOPLE 2932 (1990) (examining the differonees betwoon Aboriginal approaches to justice and "expectations of the legal system" in a paper written for the Public Inquiry into the $\Lambda$ dministration of Justice and $\Lambda$ boriginal People. Practices common in tho Euro Canadian legal system may seem "culturally and ethically foreign and opposing," and "[d]iffereñies ini value urientation causes [3ic] significant differences in behavior, and wherc Native people come into the legal context of the dominant society the situation appcare to footor bchavioral conflicts within the courtroom as well as with onforooro of tho law."); Ciokas, supra note 16, at 187 ("Aboriginal over-representation io affirmed by report after roport documenting the high contaet rates of $\Lambda$ boriginal pcople with police and their disproportionately high ratoo of arrest, conviction and imprisonment. Over-representation in prisons and jails is now an acknowledged fact, and there is every indication that the problem may bo woreoning, given that the federal $\Lambda$ boriginal inmate population is increasing at more than twioo tho national rate."); Carrul LaPrairie, The Role of Senteneing in the Over-Representation of Aborisinal Pcoplc in Correctional Institutions, 32 CANADIAN J. CRIMINOLOGY \& CRIM. JUST. 429, 429 (1990) ("For the past two decadeo, virtually, everything written and discussod in the aroa of aboriginal pooplo and the criminal justice system has used as ito otarting point the over-repreoentation of aboriginal people as inmates in federal, provincial, and territorial correctional institutions.").

61 William D. Coleman, Bridging the Cultural Divide: A Report on Aboriginal People and Criminal Justice in Canada, 29 CAN. J. OF POL. SCI. 784, 785 (1996).

52 MiNisTRY OF THE SOlicitor GENERAL, OTTAWA (ONTARIO), supra note 16, at 5, 24; TASK FORCE ON THE CRIMINAL JUSTICE SYSTEM AND ITS IMPACT ON THE INDIAN AND MeTIS PEOPLE OF ALBerta (CANADA), supra note 17, at 64 ("It is a well lenown and hiotorically peroistont fact that the Aboriginal peoples of Alberta have been dramatically and proportionately overrepresented in jails and penitentiarieo. Tasls Force reacarch has detcrminod that, ovor the past five years, the percentage of Aboriginals in jail has ranged from $29.7 \%$ to $31.5 \%$ for the total Aboriginal population. For 1989 , the most recent year, the percentage is $31.1 \%$ comparod to a $1 \%$ to $5 \%$ representation of the general population of Alberta."); see also Tim Quigley, Are We Doing Anything about the Disproportionate Jailing of Aboriginal People?, 42 CRIM. L.Q. 129, 157 (1999) (noting the proportion of Aborignial offonders who are incarcerated rather than finod groatly exceeds their population); LaPrairie, supra note 50, at 429 ("aboriginal people comprise approximately $1.5-2 \%$ of the Canadian population but make up approximately $8-10 \%$ of the fcderal corrcctional institutional population and conoidorably moro in provincial and torritorial institutions ... for certain aboriginal groups such as women and juvenilos, the rates may be oven more extreme"); DeP'T OF JuSTICE CAN., Final EVAluation ABORIGINAL Justice Strategy 12 (2000), http://publications.gc.ca/collections/collection_2007/jus/J3-6-2000-1E.pdf [hereinafter Aboriginal Justice Strategy Evaluation 2000] ("Aboriginal people continue to be overrcpresented among admisoiono to adult correctional facilitics, as $15 \%$ of provincial/territorial 
early 1990s, Aboriginal people made up between 2-3 percent of the total population of Canada, yet they made up 10-15 percent of the penitentiary population. ${ }^{53}$ In certain areas, the proportions may have been much higher. In 1992, in the prairie provinces of Manitoba, Saskatchewan, and Alberta Aboriginal people represented approximately 15 percent of the population, but their percentage of total prison population might have been as high as 60 percent. ${ }^{54}$

Initially, researchers attributed this over-incarceration of Aboriginal offonders to high lovols of crime and facially neutral policics that negatively impacted Aboriginal offenders. ${ }^{55}$ In particular, researchers blamed sentencing practices for over-incarceration and Aboriginal offenders' feelings of alienation. ${ }^{56}$ Carol LaPrairie, who worked as a researcher for the Department of Justice, wrote:

admissions are Aboriginal peoples, while they represent $2.8 \%$ of the general Canadian population . . . . The [Canadian Centre for Justice Statistics] reported that in 1997/98, the total porcentage of Aboriginal peoples sentenced to provincial/territorial probation was $12 \%$ over four timos the proportion of Aboriginal people in the Canadian population."); sec gencrally, A. C. HAMILTON \& C. M. SinClaIR, REPORT OF THE ABORIGINAL JUSTICE INQUIRY OF MANITOBA ch. 4 (1991).

53 Population by Aboriginal Groups and Sex, Showing AgE Groups, for Canada, 1996 Census (20\% Sample Data), Strats. CAN. Catalog No. 93F0025XDB96002, wWw.statcan.gc.ca/c1906 r1996/jan13.13jan/c1996.r1996 cng.pdf (last visted Feb. 12, 2016); Canadian Centre for Justice Statistics Proftle Series, Aboriginal Peoples in Canada (2001); see RoYal CoMm'n on Aboriginal Peoples, Aboriginal Peoples AND the JUstice System 30, 41 (1993); R. v. Gladue, [1999] 1 S.C.R. 688, 719 (Can.) ("If overreliance upon incarceration is a problem with the goneral population, it is of much greater concern in the sentencing of aboriginal Canadians. In the mid-1980s, aboriginal people represented about 2 percent of the population of Canada, yet they made up 10 percent of the penitentiary population. In Manitoba and Saskatchewan, aboriginal people constituted something between 6 and 7 percent of the population, yet in Manitoba they represented 46 percent of the provincial admissions and in Sackatchewan 60 percent. The oituation has not improved in recent years. By 1997, aboriginal peoples constituted closer to 3 percent of the population of Canada and amounted to 12 percent of all federal inmates.").

54 Royal COMM'N ON ABORIGINAL PEOPLES, supra note 53.

55 See, e.g., BRIDGING THE CUltural Divide, supra note 16, at 41 (citing reports that found Aboriginal offondere moro likely than non Aboriginalo to plead guilty even when they do not beliove thomgelvoe to be guilty, and they wero also loos likely to benefit from plea bargains).

56 Robert A. Silverman \& Marianne O. Nielsen, Aboriginal Peoples and Canadian Criminal Justice 122-23 (Robert A. Silverman \& Marianne O. Nielsen eds., 1992) ("Dealing with courts means dealing with the central most important isouc to Native pcoplc (or othcrs) who find thomselves facing a conviction for a violation of criminal law and that is sentencing." The Crown was less likely, in 1975, to offer a plea bargain to Aboriginal offenders and Aboriginal "cultural traito" were misinterpreted, negatively impacting $\Lambda$ boriginal offenders); REГORT OF TIE TASK Force on THE CRIMTNAL Justice System AND ITS IMPACT ON THE INDIAN AND METIS PeOPle of Alberta, supra note 47, at 6-1 (reviewing submissions and statistical data on recidiviom and concluding that "the impocition and enforcement of acntences had very littlc impact on Aboriginal persons."); BRIDGING THE CULTURAL DIVIDE, supra note 16, at 309 ("The Canadian criminal justice system has failed the Aboriginal peoples of Canada-First Nations, Inuit and Metis people, on-reserve and off reserve, urban and rural-in all territorial and 
Nowhere else is the use of the criminal justice system to address a major social and economic problem so potentially problematic as it is in relation to [A]boriginal people. It is this group which appears to be incarcerated for less serious offences because its members do not qualify for probation, and few options but incarceration are available to judges. ${ }^{57}$

Ultimately, reports explained Aboriginal confrontation with the criminal justice system as a conflict between two sets of justice values. ${ }^{58}$ By comparing Euro-Canadian and Aboriginal justice principles and approaches to crime, inquiries revealed the extent to which the criminal justice system was alien and oppressive to Aboriginal people. ${ }^{59}$ For example, Judge Murray Sinclair, Co-Commissioner of the Aboriginal Justice Inquiry of Manitoba, compared Euro-Canadian punishment and deterrence approaches to Aboriginal justice principles. While acknowledging that there was no universal Aboriginal conception of justice, he explained an Aboriginal conception of justice "would be that of restoring peace and equilibrium to the community through reconciling the accused with his or her own conscience and with the individual or family that [was] wronged." 60 By comparison, Euro-Canadian justice considers offenders to be harmful to society and punishes them in order to deter harmful, deviant behavior by that offender and others in the future. 61

governmental jurisdietions. The principal reason for this crushing failure is the fundamentally different world views of Aboriginal and non Aboriginal people with reapect to such olomontal issues as the substantive content of Justice and the process of achieving Justice.")

${ }^{57}$ LaPrairie, supra note 50 , at 437.

68 See, e.g., DumonT, supra note 50, at 28; Leonard Mandamin, Aboriginal Justice Systems, in ABORIGINAL PEOPLES AND THE JUSTICE SYSTEM 275, 281 (Royal Commission on Aboriginal Pcoples eds., 1993) ("For Aboriginal people the emphasio is on restoration and healing rathor than punishment"); BRIDGING THE CULTURAL DIVIDE, supra note 16, at 309; Murray Sinclair, Aboriginal Peoples, Justice and the Law, in CoNTINUING POUNDMAKER AND RIEL's QUEST: A Compmation of the PResentations Made At a Conference On Aboriginal Peoples aND JUSTICE 178 (Richard Gosse et al. eds., 1994) (". . . the question should be restated as: "What is wrong with our justice system that Aboriginal people find it so alienating?' . . . . [The starting point] requires one to come to torms with the conecpt that $\Lambda$ boriginal Pooplos of North $\Lambda$ merica, for the most part, hold world views and life philosophice fundamentally difforont from those of the dominant Euro Canadian socicty, and that these belief systems and approaches to life aro so fundamentally different as to be inherently in conflict."); sec senerally REPORT OF THE TAEK FORCE ON THE CRIMINAL JUSTICE SYSTEM AND ITS IMPACT ON THE INDIAN AND METIS PEOPLE OF ALBERTA, supra note 47; HAMILTON \& SINCLAIR, sipra note 52, at ch. 2; see also Kwochlra, oupra. note 49 , at $159-60$.

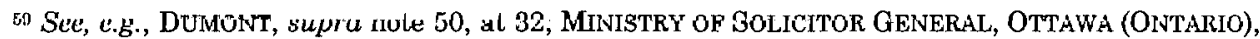
supra note 16, at 28-31; BRIDGING THE CULTURAL DIVIDE, supra note 16, at 58 ("It is difficult and disturbing to realize that Aborigina! ponple see the non-Aboriginal justire system as alien and repressive, but the evidence permits no other conclusion.").

60 Sinclair, supra note 58.

${ }^{61} I d$. 
In its position paper on incarceration, the Community Holistic Circle Healing Program: Hollow Water First Nation, ${ }^{62}$ also compared the two approaches to justice as follows:

Our tradition, our culture, speaks clearly about the concepts of judgement and punishment. They belong to the Creator. They are not ours .... People who offend against another (victimizers) are to be viewed and related to as people who are out of balance - with themselves, their family, their community, and their Creator. A return to balance can best be accomplished through a process of accountability that includes support from the community through teaching and healing. The use of judgement and punishment actually works against the healing process. An already unbalanced person is moved further out of balance ....

The adversarial approach also places the victimizer against his or her community. As we see it, this goes against the very essence of the healing process. For us, healing (breaking the cycle) is based on (1) the victimizer taking full responsibility for his/her actions, (2) the victim understanding and integrating this into day-to-day living, and (3) the COMMUNITY being able to support, assist, and/or hold accountable all the parties of the victimization. Until this can happen, and as long as incarceration is seen as the solution, the community will not be a safe place. ${ }^{63}$

Because of these fundamentally different worldviews of justice, Aboriginals participating in the non-Aboriginal justice system was itself an experience of colonization. ${ }^{64}$ Task forces and commissions found that assuming greater responsibility for the delivery and administration of justice

62. The Hollow Water Initiative cerves First Nation and Metis in four communitics: Manigotagan, Aghaming, Soymourville, and Hollow Water. For additional information about the Community Holistic Circle Healing Program, soe Ed Buller, Aboriannal Community Healmig Procegses IN CANADA 3-8 (2005)

63 THE CHURCh CoUNCIL ON JUSTICE \& CORRECTIONS, supra note 18, at XXIII-XXV.

64 BRIDGING THE CULTURAL DIVIDE, supra note 16 ("In making the case for Aboriginal control of 'Justice', the RCAP begins by recognizing that [it] has been through the law and the administration of juotico that $\Lambda$ boriginal people have experienced the most reprcosive aspects of colonialiom. Tho RCAP then proposed that it is in Aboriginal law, with $\Lambda$ boriginal law and through Aboriginal law that Aboriginal people aspire to regain control over their lives and communitico. The cotablishment of oystems of $\Lambda$ boriginal justice is accn as a ncecssary part of throwing off the suffocating mantle of a legal system imposed through colonialism."). These issues are examined more closely in Toby S. Goldbach, Sentencing Circles, Clashing Worldviews, and the Case of Christopher Pauchay, 10 LLLUMINE: J. OF THE CTR. FOR STUD. IN RELIGION AND SOC'Y GRADUATE STUDENTS ASS'N 53, 66-68 (2011). 
was imperative, and ${ }^{65}$ most agreed that Aboriginal people possessed the legal and constitutional authority to administer justice. ${ }^{66}$ Canada identified two options: (i) recognize the right to a separate parallel justice system for Aboriginal people, or (ii) incorporate Aboriginal justice into the existing criminal justice system. ${ }^{67}$

\section{B. Bridging the Gap}

During the 1990s, Canadian authorities effectively transplanted Aboriginal healing circles as "sentencing circles" into the criminal trial. This alternative sentencing theory, and others, presented an attractive remedial approach that recognized Aboriginal authority to administer justice. Since Canadian criminal scholars and practitioners were already attacking the foundations of deterrence and incarceration in response to crime, ${ }^{68}$ Aboriginal

6 See Communication Division, Ministry of THE Solicitor General, Native Peoples AND JustiCE: RePORTS ON THE NATIONAL CONFERENCE AND THE FEDERAL-PROVINCIAL CONFERENCE ON NATIVE PEOPLES AND THE CRIMINAL JUSTICE SYSTEM 14-16, 25-26, 38 (1975) (explaining that many of the reports and commissions attribute sentencing conflict to $\Lambda$ boriginal oxcluoion from the design and delivery of justice services in Canada. It was at the National Conference on Native Peoples and the Criminal Justice Syotem that concern about Aboriginal experience was first linked to Aboriginal exclusion from the design and delivery of justice services: "The following guidelines... were regarded and adopted ... as a statement of general philosophy underlying any approach to the problems of natives within the criminal justice system. 1 . Native persons should be closely involved in the planning and delivery of services associated with criminal justice and native peoples. 2. Native communities chould have groator rooponoibility for the delivery of criminal justice services to their people . . ..").

66 See, e.g., BRIDGING THE CULTURAL DIVIDE, supra note 16; James C. MacPherson, Report from the Round Table Rapporteur, in ABORIGINAL PEOPLES AND THE JUSTICE SYSTEM 1, 6 ("One of the more promising themes of the Round Table was the absence of potential jurisdictional impediments to reform in the justice area . . . most of the participants at the Round Table appearcd to agrec with Patrick Macklem's analyoio in his papor dealing with the relationship between the current eonstitutional framework in the juotice fiold and now Aboriginal juctice systcms. Professor Macklem stated, In my vicw, neither the eurrent dictribution of logiolativo authority nor the judicature provisions pose any ocrious impediment to the catabliohment of a separate or parallel system of justice for Aboriginal people, although federal-provincial cooperation may be required to vest Aboriginal courts with jurisdiction over certain subject matters.").

67 Giokas, supra note 16, at 201 ("The solutions most commonly discussed are a soparate juctico system for aboriginal peoples, parallel systems or considerable accommodation within the existing justice system." Giakas argued that both projecto "must be undertalron to oliminate systemic diacrimination. . . there must be movement on these two simultanoous projects: developing internal community justice structures; and improving the overall justice system. The latter can be accomplishod on the basis of the many recommendationo to this effect in the various inquiry report3 and can be begun on a unilateral basis by government. Both levelo of government have already started on this latter project; howevor haltingly, and will no doubt outlino thoir efforts to this Commission in another forum."); ROYAL COMM'N ON ABORIGINAL PEOPLES, supra note 53; see also SILVERMAN \& NIELSEN, supra note 56.

68 See Canadian Sentencing Commission, Sentencing Reform: A Canadian Approach: Report of THE CANADIAN SENTENCING COMMISSION xxviii (1987) (Deterrence, rehabilitation, and incapacitation "are clearly pragmatic," novortheloss: "[e]vidonce dooo not oupport the notion 
justice advocates could burrow themselves within the larger debates about sentencing. Despite vast differences, law reformers, judges, and scholars began to acknowledge parallels between "informal justice" approaches that stressed communitarianism and interdependency, ${ }^{69}$ and Aboriginal methods for dealing with harm to the community.

Specifically, researchers pointed to the potential of restorative justice to bridge the gap between Aboriginal and Euro-Canadian approaches to sentencing. ${ }^{70}$ Aboriginal and restorative justice approaches were seen as overlapping in their goal to heal "the relationships that have been jeopardized by the wrongdoer's behavior."71 Given that North America, Europe, Australia, and New Zealand had already begun to implement restorative justice initiatives scholars, practitioners, and law reformers could

that variations in sanctions . . a affect the deterrent value of sentences. In other words, deterrence cannot be used; with empirical justification, to guide the imposition of sentences. Thore are no comprehencive data that support the idca that courta can ... impose sanctions that have a reasonable likelihood of rehabilitating offenders . . . . [And, the] extensive literature on incapacitation suggests that as a crime-control strategy the costs of imprisonment far outweigh the benefits achieved in reducing crime."); STANDING COMMITTEE ON JUSTICE \& SOLICITOR GENERAL, TAKING RESPONSIBLITY: REPORT OF THE STANDING COMMITTEE ON JUSTICE AND SOLICITOR GENERAL ON ITS REVIEW OF SENTENCING, CONDITIONAL RELEASE AND RELATED ASPECTS OF CORRECTIONS (1988); see also Julian V. Roberts, Sentencing in Canada: The Context for Reform, 32 CANADIAN J. CRIMINOLOGY \& CRIM. JUST. 381 (1990) (summarizing federal government initiatives, as well as the work of the Law Reform Commission of Canada, to produce proposals for sontoneing reform focused on the reduction of imprisonment); Anthony $N$. Doob \& Voula Marinoe, Reconccptualizing Punishment: Understanding the Limitations on the Use of Intermediate Sanctions, 2 U. CHI. L. SCH. RoundTaBLE 413, 417-21 (1993) (tracing the movement to support non-prison forms of punishment by reviewing the history of federal govornment initiativos to reform sentencing in Canada; and specifically noting statements by the Canadian Sentencing Commission chair, "a former Royal Canadian Mounted Police officer known for his far-right viowo on criminal justice matters, [which] stunned many obscrverz by explicitly rejecting ... the view that increased imprisonment would reduce levels of crime in Canadian society").

${ }^{69}$ Carol LaPrairie, Aboriginal Crime and Justice: Explaining the Present, Exploring the Future, 34 CAN. J. CRIMINOLOGY \& CRTM. JUST. 281, 282 (1992).

70 See, e.g., LAW COMM'N. OF CAN. \& DENNIS COOLEY, FROM RESTORATIVE JUSTICE TO TRAnsformative JUSTICE Discussion PAPER (1999) (stating that a restorative justice 'movoment' began in the oarly $1970 \mathrm{~s}$ based on worls done with two young offendere arrested for' vandalism in Kitchener, Ontario. Within the criminal justice system, restorative justice froquontly consistod of victim-offender reconciliation and family group confercnecs. Family conferencing is an excellent examplo of why rostorative justice and Aboriginal approaches to justice should not bo conflated. Family group conferencing relice on the family's ability to crolsc shamo and show disapproval, which contradicto ccrtain Aboriginal culture and justicc practiccs); Kwochka, supra note 49, at 156 (arguing that recommendations to include Aboriginal inwolvement in the decign and delivery of justice services "having more recognition of Aboriginal culture and law" are most promising "because they fit with a new and vibrant philosophy of criminal justice ... [which] involves a fundamentally different approach to the criminal justice syetem that can be loooely characterized under the heading of 'restorative justicc."'); Quiglcy, supra noto 52, at 111 ("Restorative justico is a throwback to the ways of dealing with wrongdoing in many indigenous societies."); Lilles, supra note 20.

${ }^{71}$ Quigley, supra note 52, at 144. 
appeal to "culturally appropriate" programs within already existing structures. ${ }^{72}$ Eventually, perceptions about Aboriginal approaches to crime converged with the idea of restorative justice. ${ }^{73}$ For example, in a case decided by the Supreme Court of Canada in February 2000, Justice Iacobucci, on behalf of the Court, wrote: "most traditional [A]boriginal conceptions of sentencing hold restorative justice to be the primary objective," and their "approaches place a primary emphasis on the goal of restorative justice."74

In 1996, Canadian lawmaliers codified a broader movement away from deterrence and incapacitation in new sentencing provicions of the Canadian Criminal Code. ${ }^{75}$ Thus, transplanted Aboriginal methods received legislative support and increased exposure. Based on the recommendations of a Fedoral Standing Committee on sentencing, the federal government enacted sweeping changes to the Criminal Code, including new provisions expressly articulating the purposes and principles of sentencing. Still in force, Section 718 outlines the purposes of sentencing for all offenders, including restorative and reparative justice goals. ${ }^{76}$ In addition to denunciation, deterrence, and other traditional sentencing objectives, judges can also craft sanctions "to promote a sense of responsibility in offenders, and acknowledgment of the harm done to victims or to the community." 77 Section 718.2 introduces "other sentencing principles," which requires judges to take into account the goals of predictability and ensures that the offender's liberties are not deprived if less restrictive measures are appropriate. ${ }^{78}$ More pointedly, Section 718.2(e)

72 MINISTRY OF SOLICITOR GENERAL, OTTAWA (ONTARIO), supra note 16; see also LAW REFORM Commission of Canada, Report on Aboriginal Peoples and Criminal Justice Equality, RESPECT, AND THE SEARCH FOR JUSTICE AS REQUESTED BY THE MINISTER OF JUSTICE UNDER SUBSECTION 12(2) OF THE LAW REFORM COMMISSION ACT (1991) (stating that with "very little adjustment," restorative justice programs in place in Correctional Services would be able to "incorporate customary law, thus increaoing their acecptability to the affectod population"). But see Jennifer .J. I.lewellyn, Dealing with the Iegary of Native Residential School Abuse in. Cannda: Litigation, $A D R$, and Restorative Justice, 52 U. TORONTO L. J. 253 (2002) (presenting an opposing view).

${ }^{73}$ Llewellyn, supra note 72; see, Lilles, supra note 20 (explaining the process of 'circle sentencing' as an example of a restorative justice initiative).

${ }^{74}$ R. v. Wells, [2000] 1 S.C.R. 207, paras. 37-38 (Can.).

${ }^{75}$ Criminal Cade, R.S.C. 1985, c C-46, s. 718(e)-(l). In addition to the principles of delerrence and denunciation, the criminal code stales that "just sanctions" include the objectives of providing reparations, and promoting a conco of rocponcibility in offendoro and acknowledging harm dono to victims. The new eentencing provioione aloo introduced $\Lambda$ lternative Meacures (o. 717) and the Condilional Sentence of Imprisumuent (s. 742) as options for sentencing uffenders. See discussiùn of conditional sentencing infra note 80 .

${ }^{76}$ Criminal Code, R.S.C. 1985, c C-46, s. 718 (a)-(f) (stating that the objectives of sanctions include: (a) denunciation, (h) deterrence, (c) removal, (d) rehabilitation, (e) reparations, and (f) promoting a sense of responsibility in offenders).

${ }^{77}$ Id. s. $718(\mathrm{f})$.

${ }^{78}$ Id. s. $718.2(\mathrm{~b}),(\mathrm{d})$. 
mandates that judges consider all alternatives to imprisonment and give "particular attention to the circumstances of Aboriginal offenders."79

Some judges were already conducting sentencing circles prior to these amendments pursuant to their discretion. However, these amendments to the Criminal Code gave judges legislative authority to transplant Aboriginal practices into the criminal trial. ${ }^{80}$ Courts held that the sentencing principles delineated in Section 718.2(e) instruct judges to consider those sentencing procedures that may be appropriate because of the offender's Aboriginal heritage. For example, in a case decided shortly after the new sentencing provisions came into effect, Alberta Provincial Court Justice Marshall interpreted 718.2(e) as providing the legal authority to conduct a sentencing circle. Regarding the language "with particular attention to the circumstances of Aboriginal offenders," Justice Marshall wrote:

This suggests to me that additional tools that are unique to [A]boriginal people such as sentencing circles, traditional healing methods, respect for the advice of elders, etc., should be utilized where reasonably possible and that special recognition should be given to the native traditional way of life, and the effects that the removal from that community, and way of life, would have upon an [A]boriginal offender.

Such an approach, it is hoped, would make the justice system more just, meaningful and acceptable to the aboriginal people. ${ }^{81}$

Considering the circumstances of Aboriginal offenders goes beyond merely inquiring into the offender's socio-economic circumstances. It also roquires a different approach and a willingness to address crime by utilizing those additional tools, which include sentencing circles, that are available to $\Lambda$ boriginal offenders as members of that community. ${ }^{82}$

${ }^{79}$ Id. s. 718.2 ("A court that imposes a sentence shall also take into consideration the following principles ... (e) all available sanctions, other than imprisonment, that are reasonable in the circumstances.. should be considered for all offenders, with particular attention to the circumstances . . . of Aboriginal offenders.").

${ }^{80}$ In addition to directing judges to consider express statements of the purposes and principles of sentencing, the amendments to the Criminal Code introduced the conditional sentence of imprisonment as a sentencing option. See Criminal Code, R.S.C. 1985, c C-46, s. 742.1 (explaining that if the offense is not subject to a mandatory minimum sentence and the final centence is for a pcriod of leas than two years, the judge can order a term of imprioonment to be aorved in the community rather than in a correctional facility). Conditional sentences greatly impact the uso of senteneing circles in criminal trial by providing a framework and a form of Bontence for tho typos of recommendations that centencing cireles often craft. Scc infra Part III.B.

81 R. v. R. (H.) (1997), 205 A.R. 226, para. 53 (Can. Alta. P.C.).

82 The Supreme Court of Canada had the opportunity to consider Section 718.2 (e) in Gladue, 1 S.C.R., and then shortly thereafter in Wells, 1 S.C.R. In Gladue, the Court noted the emergence 
During roughly the same period sentencing circles were being transplanted into the criminal trial, the Aboriginal Justice Initiative (19911996), and its successor, the Aboriginal Justice Strategy (1996-present), provided a bureaucratic structure for Aboriginal justice programs. ${ }^{83}$ The federal government-in cooperation with Indian and Northern Affairs Canada, the Privy Council Office, the former Office of the Solicitor General (now Public Safety Canada), and the Royal Canadian Mounted Policedeveloped initiatives to foster programs that could "be the foundation of long term administration of justice improvements within the framework of the Canadian law for Aboriginal people." 84 In partnership with provincial and territorial governments, the federal government funded "community-based justice programs" on a cost sharing basis, which included contencing circles, training, and development related to justice programs. ${ }^{85}$

of "innovative sentencing practices, such as healing and sentencing circles, and aboriginal community council projects, which are available especially to [A]boriginal offenders." 1 S.C.R. I] 74. While it declined to discuss sentencing circles in detail, the Court did write that "[t]he background considerations regarding the distinct situation of [A]boriginal peoples in Canada" included "[t]he types of sentencing procedures and sanctions which may bc appropriate in the circumstances for the offender because of his or her particular aboriginal horitago or connoction." Id. I 66.

83 Dept. of Justice Can., Aboriginal Justice Strategy Evaluution Final Report (2011) [hereinafter ABORIGINAL JUSTICE STRATEgy EVAluation 2011]; DON ClaIRMONT \& JANE

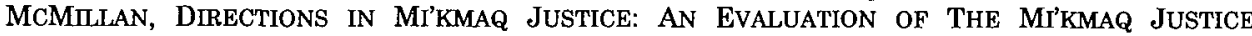
INSTTTUTE AND ITS AFTERMATH 12-13 (2001) (describing the Aboriginal Justice Directorate's (" $\Lambda J D ")$ emphacis on restorative juetice and community justice enmmittees: "The major emphasis of the [Aboriginal Justice Learning] Network [an initiative of tho AJD] has boon on restorativo justice, linking aboriginal traditions and preferences (e.g., circle sentencing) with new developments such as family group conferencing.").

84 ABoriginal Justice Strategy Evaluation 2000, supra note 52, at i.

85 ABoriginal JUSTICE STRATegy Evaluation 2011, supra note 83, at 5 . The government also funded program development for communitico that did not havo $\Lambda$ boriginal Justico Stratogy funded programs. Id. Sinco 1996, the Aboriginal Justice Strategy has been renewed twice for five year mandates. Id. at 5 . In $2006-07$, the fund supported approximately 100 programs. Id. at 5 . By 2011-12, it funded 214 community programs. Id. In fiscal year 2013-2014, the federal government spent $\$ 11$ million funding the $\Lambda$ boriginal Justice Strategy, with a total commitment to provide \$22.2 million over two years. Aboriginal Justice Strategy, CANADA's ECON. ACTION PLAN, http://actionplan.gc.ca/en/initiative/aboriginal-justice-strategy (last visited Dec. 16, 2015). Aboriginal Justice Strategy funded "Community Justice Committees" that often arrange sentencing circles; they may specify procedures to be followed prior to, and at the sentencing circle, make decisions about who participates in the circle, and may also identify a local community leader to act as keeper of the circle. See generally ABORIGINAL JUSTICE STRATEGY Evaluation 2000, supra note 52, app. A. For example, the Yukon Tribal Council Community Based Justice Initiative developed protocols and guidelines for sentencing circles, and the F.Iders Panol of the Waywayseecappo Aboriginal Instice Program sits with the provincial court and offers recommendations on sentencing. Id. at 81, 92. See also R. v. Johns (J.C.), [1995] B.C.W.L.D. 299, para. 9 (Can. Y.K.C.A.) (describing the application proceso to tho Kwanlin Dun Community Justice Committee for a eentencing circle, and the process to sot up a rohabilitation program before the sentencing circle is held); R. v. Craft, [2006] Y.K.T.C. 19, paras. 30-31 (Can.); R. v. Van Bibber, [2010] Y.K.T.C. 49, para. 31 (Can.) (noting the role of the Northern Tutchone Council, also funded by the Department of Justice through the Aboriginal Courtwork Program, 


\section{Sentencing CiRCLe OutComeS}

\section{A. Sentencing Circles in the Criminal Trial}

Following standard comparative law and legal transplant methodology, ${ }^{86}$ this Part examines the effects of importing Aboriginal healing circles into the sentencing phase of the criminal trial. This section presents data compiled from a review of all adult criminal trials and appeals dealing with sentencing circles to see how the reforms operate in action and to what extent the system is receptive to the new legal transplant. 87

Before presenting this data, this Article introduces the issues and concerns via a difficult, but emblematic, case. The facts are as follows. Sometime between midnight and 5:00 AM, a father lost his two daughters in the field by his house. ${ }^{88} \mathrm{He}$ was attempting to cross the field to get to his brother-in-law's house to find help for his youngest daughter who he thought was hurt.89 "Both girls died of hypothermia."90 The father "pled guilty to criminal negligence" causing death. ${ }^{91}$ At trial, he asked for a sentencing circle to be held. ${ }^{92}$ The court granted the request, held the sentencing circle, and then delivered the sentence, which included a three-year prison term in a federal penitentiary. ${ }^{93}$

The level of controversy and vitriol around the judge's decision to hold the sentencing circle was robust. One reporter likened a sentencing circle to "a group hug for both victims and offenders." 9 . Another intirnated that given the chance, the contencing circle's recommendation to the defendant would be to "go stand outside in a snowbank until you're a Popsicle."95 Against these

in conduoting the sontoncing circle); see also, STUART, supra note 19, at 33; Clairmont, supra note 16, at 131-146 (discussing the Indian Brook justice initiative in Nova Scotia in comparison to Aboriginal justice programs in Northorn Ontario and Metropolitan Toronto).

${ }^{86}$ Lasser, supra note 33; Michele Graziadei, The Functionalist Heritage, in CoMPARATIVE LEGAL STUdies: 'TRAdiTIONS AND TRANSITIONS 100 (Pierre Legrand \& Roderick Munday eds., 2003); Langer, supra note 8.

${ }^{87}$ Berkowitz et al., supra note 6.

${ }^{88}$ R. v. Pauchay (2009), 328 Sask. R. 173, paras. 14-18 (Can. Sask. P.C.).

${ }^{89}$ Id. I 18.

${ }^{80} \mathrm{Id}$. $\mathrm{q} 17$.

91 Id. ๆ 1.

92 Id.

${ }_{93}$ R. v. Pauchay (2009), 333 Sask. R. 167, paras. 1, 69 (Can. Sask. P.C.) [hereinafter R. $v$. Pauchay (II)].

${ }^{94}$ Kevin Libin, Sentencing Circles for Aboriginals: Good Justice?, NAT'L PosT (Feb. 27, 2009, 8:01 PM), http://www.nationalpost.com/news/story.html?id=1337495.

95 Colby Cosh, Squaring the Circle on Justice, NATL PosT (Nov. 7, 2008), http://www.nationalpost.com/opinion/story.html?id=4252cc77-d93f-4749-a757-fd54fe8fd229. 
protestations stands the amount of time and effort the community expended. Twenty-three people participated in an inner circle including: the victims' mother, two members of the community who sat as surrogates for the victims, the defendant's parents, senior elders from Sturgeon Lake First Nation and the Yellow Quill First Nation, interpreters, the judge, and other justice representatives. ${ }^{96}$ Another fifty to sixty people observed. ${ }^{97}$ The circle met for five hours. In advance of the sentencing circle, member of the reserve spent additional time in healing circles held by the defendant's family. ${ }^{98} \mathrm{In}$ addition, a mental health specialist conducted interviews to prepare an intervention strategy. ${ }^{99}$

The participants made various recommendations. For example, the mental health specialist recommended intervention strategies, such as workshops to tearh parenting and life skills, mentoring programs for youths, and a helpline for children. ${ }^{100} \mathrm{~A}$ community elder recommended that defendant serve the elders, acting as a cultural helper and assisting with ceremonial duties, such as setting up rocks for sweat lodges and filling and lighting pipes before ceremonies.101 The defendant would be required to abstain from alcohol and drugs while in that role and would receive guidance from the elders. 102 The role would be for life and serve as "a reminder that the Creator had not left him." 103

When he announced the decision, the judge thanked the participants, noting that the sentencing circle had given him "valuable insight" into the community's views of the problems it faces. ${ }^{104}$ The judge, however, noted that he did not have the authority to order something that would amount to probation for more than three years. ${ }^{105}$ His decision was that a proper balancing of the sentencing principles required incarceration for three

\footnotetext{
${ }^{96}$ R. v. Pauchay (II), supra note 93, para. 47.

${ }^{97}$ Goldbach et al., supra note 8 , at 56.

${ }^{98}$ Id.

${ }^{99}$ Id. at 59; R. v. Pauchay (II), supra note 93, para. 48.

100 Goldbach et al., supra note 8, at 59; R. v. Pauchay (II), supra note 93, para. 48 (providing a statement by the court regarding the recommendations made by the mental health specialist: "Dr. Raj Hathiramani, the mental health therapiat at Yellow Quill Firet Nation, provided a compreheneive community healing plan that contained twelvo opecific recommendations, como that were designed to address community issues well beyond the scope of the Sentencing Circle"). For a discussion on judicial recitation of sentencing circle recommendations see infra Part IV.
}

${ }^{101}$ R. v. Pauchay (IT), supra note 93, para. 51.

${ }^{102}$ Goldbach et al., supra note 8, at 57.

${ }^{103}$ R. v. Pauchay (II), supra note 93, para. 51.

${ }^{104}$ Id. ๆ 53.

${ }^{105}$ Id. ๆ 69 . 
years. ${ }^{106} \mathrm{He}$ wrote that it would be up to Mr. Pauchay, following his incarceration, to decide whether he wanted the support of the Yellow Quill First Nation. ${ }^{107}$

It seemed everyone did everything right; an alternative, culturally appropriate process was used and the judge engaged in the proper legal analysis. Yet, because so many people spent so much time to work on recommendations-only to have the judge say "thank you"-one can easily find themselves frustrated and perturbed when reading the case. Again juries are generally not involved in sentencing in Canada, but once we do involve the community and ask them to participate, is there any duty on the judge to adopt any part of the sentencing recommendations or to consider them in a particular way?

\section{B. Requests for Sentencing Circles}

Taking a macro view, what follows is a review of the treatment of sentencing circles in all cases where judges considered them during the course of an adult criminal trial under the Canadian Criminal Code. ${ }^{108} \mathrm{~A}$ search for the phrase "sentencing circle" and "circle sentencing" generated 103 distinct hits. ${ }^{109}$ These 103 hits included motions, final declarations or dispositions on sentencing, appellate level decisions of cases relating to sentencing circles, as well as cases that referred to the sentencing circle process, but where sentencing circles were not actually conducted in the trial.

The cases were initially divided according to whether they related to requests for sentencing circles, trials where sentencing circles were held, or cases where the parties appealed. Appeals could consist of reviews of docisions of whether to hold a sentencing circle, or reviews of the sentence

${ }^{106} \mathrm{Id}$.

107 Id.

108 This will capture all published criminal trial decisions in Canada. Through online databases, such as LexisNexis, Quicklaw, and the Canadian Legal Information Institute ("CanLII"), Canadian courts publish all judgments on criminal code matters, including appellate decisions and docisions of lower and higher court judges who are provincially and federally appointed, respectively. What this does not include are caves that are diverted from the crininal justiec syotem, and young offendoro who may go through the sentencing circle proceos, but whose docisions remain unpublished. Therefore, there will be an amount of activity that is not covercd by this roviow. Howover, in co far as the roformo were meant to provide Aboriginal communitios with authority over the design and delivery of juotice sorvices, implementation and outeomes within the adult oriminal trialo provide highly relevant information.

${ }^{109}$ The initial search did not yield $R$. v. Moses, [1992] B.C.W.L.D. 1293 (Can. Y.K.T.C.). The judge in that case, Territorial Court Judge Stuart, only used the terms "circle process" or "circle discussions." Moses, [1992] 71 C.C.C., paras. 81, 86, 100, 103, 110, 113, 169. The data presented in this Article includes $R$. v. Moses because it is widely acknowledged as the first case where this procese was used. The data ineludes the first case and reflecto the transition in judicial discourse towarde roforring to the proooso ao "oirclo sentencing" or a "sentencing circle." 
itself when a sentencing circle was held. Of the cases that were reviewed, there were forty eight cases in which a request for a sentencing circle was made to a judge. ${ }^{110}$ Of the forty-eight cases in which a defendant made a request before a judge to hold a sentencing circle, judges allowed a circle to be held in thirty-seven cases. ${ }^{111}$ The table below indicates the number of requests for sentencing circles per year.

\section{Table 1: Did the judge allow a request for a sentencing circle? (1992- 2010)}

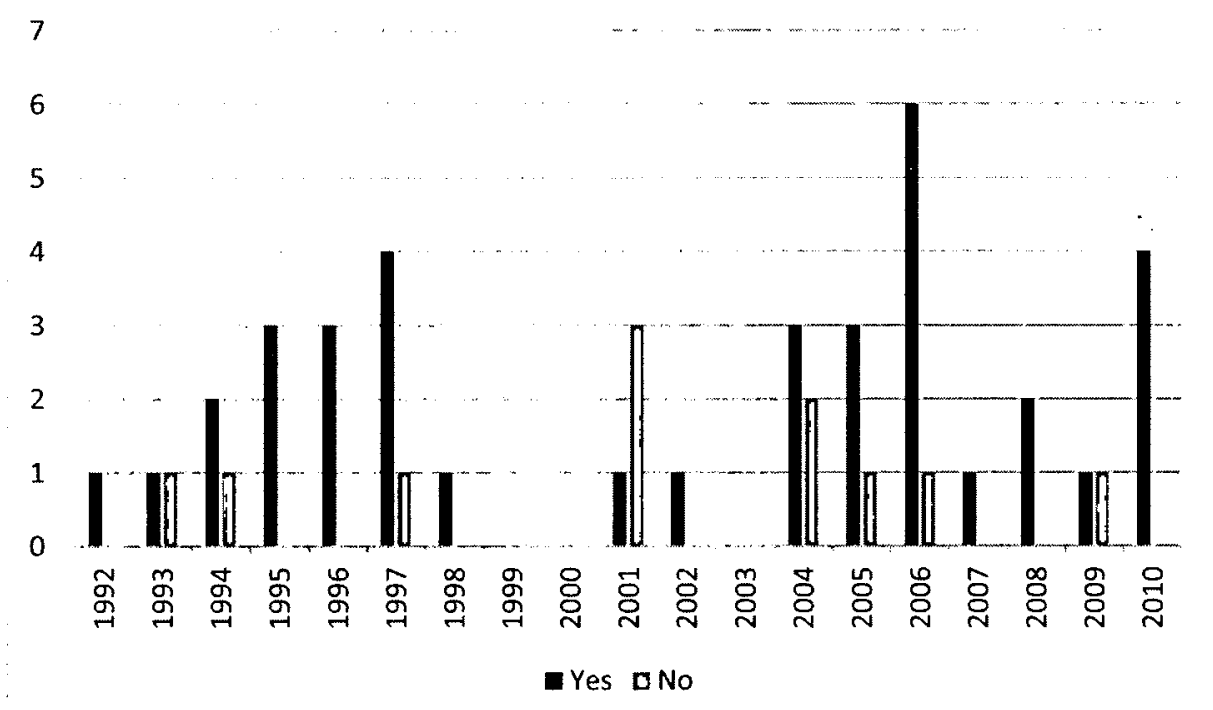

Viewed in the aggregate, the data seems to indicate that judges were favorable to allowing sentencing circles. However, the data looks different when focusing on reported decisions in which the judge actually considered the request as a motion on the merits. Of the sixteen cases where the request

${ }_{110}$ These forty eight cases include decisiono in which the judge documented the dioposition on a formal application to the court in a distinct decision, as well as cases whoro a dispocition was inferred from reported ocntencing decioiono or appellate level decisions. In come of tho docioiono, the court had already held a senteneing circle and the trial judge delivered the eentonco. In thoco casce, cither the Crown conoonted to the request for a sentoncing circlo or the judgo hold a hearing but did not write reasons regarding the request. See, e.g., R. v. Kahypeasewat (2006), 284 Sask. R. 55, paras. 6266 (Can. Sask. P.C.) (court held a oentencing circle; judgo only wrote reasono for the final decision on oentencing). The Crown consented to the holding of a sentencing circle in R. v. Manyfingers (C.J.) (1996), 191 A.R. 342 (Can. Alta. P.C.); R. v. Paul (D.) (1998), 203 N.B.R. $2 d 243$ (Can. N.B.P.C.); and R. v. Brooks, [2008] N.S.P.C. 58 (Can.). The data tabulating requests for sentencing circles is presented in Appendix A of this Article.

111 For the full list of cases, see Appendix A. 
was contested, or the judge considered it as a motion on the merits and wrote reasons for the decision, judges denied eleven of the requests for a sentencing circle. ${ }^{112}$ In three cases, the judge held a hearing or discussed reasons for allowing a sentencing circle even though the Crown already consented. ${ }^{113}$

The table below shows no discernible trend in the number of requests allowed over the examined period, which suggest consistency in judicial attitudes towards conducting sentencing circles. Although, there was a considerable decline in requests for sentencing circles between 1998 and 2004 , which may be the result of unfavorable decisions in early appeals of trials that implemented sentencing circles. ${ }^{114}$

In all jurisdictions, judges developed criteria to consider in determining whether a particular case was appropriate for a sentencing circle. In Saskatchewan, trial courts consider seven criteria, which were originally articulated by Provincial Judge Fafard in $R$. $v$. Joseyounen. ${ }^{115}$ British Columbia trial courts adopted these seven criteria, ${ }^{116}$ whereas the Newfoundland and Labrador Court of Appeal reviewed the criteria and adopted five of the seven factors for their courts. ${ }^{117}$ The relevant factors that judges consider when determining whether to allow a sentencing circle present similar themes, especially with regard to issues relating to the accused, the victim, and the community's participation. The table below amalgamates the criteria, which appear across all provinces, and identifies

112 See Appendix A.

${ }^{113 R}$. v. Nicholas (B.L.) (1996), 177 N.B.R. 2d 124 (Can. N.B.P.C.); Paul (D.), 203 N.B.R. 2d 243; Brooks, [2008] N.S.P.C. 58, para. 2 (referring to principles set out in R. v. J. (J.) (2004), 244 Nfld. \& P.E.I.R. 24 (Can. Nfld. \& Lab. C.A.) on whether to allow a request for a sentencing circle, however, the Court indicates that the Crown's consent made it unnecessary to determine the issue of the request); see also R. v. Stick (C.) (2001), 202 Sask. R. 306, para. 10 (Can. Sask. Q.B.) (otating that, on appeal, the court determined that the trial court judge crred by reversing his prior decision to allow a sentencing circle without hearing submissions from the parties).

114 Luke McNamara, Appellate Court Scrutiny of Circle Sentencing, 27 MANITOBA L.J. 209, 225 (2000).

115 R. v. Joseyounen, [1995] 6 W.W.R. 438 (Can. Sask. P.C.). The Saskatchewan Court of Appeal approved Fafard's criteria in R. v. Morin (I.) (1995), 134 Sask. R. 120 (Can. Sask. C.A.), and then again in $R$. $v$. Munson (2001), 214 Sask. R. 26 (Can. Sask. Q.B.). The seven criteria are: (1) the accueed must agroe to be referred to the contencing circle; (2) the accused must have decp rooto in the community; (3) there are clders or respected non political community lcaders willing to participate; (4) the victim is willing to participate and has been subjected to no coercion or proseure; (5) tho victim has counseling made available and io accompanicd by a support tcam if ohe has battcred spouse syndrome; (6) disputed facts have been resolved in advance; and, (7) the Court ic willing to depart from the usual range of sentencing.

116 R. v. Pena (M. J.) (1997), 148 D.L.R. 4th 372 (Can. B.C.S.C.).

117 J. (J.), 244 Nfld. \& P.E.I.R. 24; see also STUART, supra note 19. 
which factors were considered when denying a request for a sentencing circle. ${ }^{118}$

Table 2: Which factors were considered in denying a request for a sentencing circle?

\begin{tabular}{|c|c|c|}
\hline $\begin{array}{l}\text { Factors to consider in } \\
\text { allowing/denying request for } \\
\text { sentencing circle }\end{array}$ & $\begin{array}{c}\text { \# of times } \\
\text { referred to as } \\
\text { reason for } \\
\text { denying request }\end{array}$ & $\begin{array}{l}\text { Province and } \\
\text { Court, } 119 \text { Year } \\
\text { of Decision }\end{array}$ \\
\hline $\begin{array}{l}\text { Accused does not appear to have } \\
\text { accepted responsibility }\end{array}$ & 2 & $\begin{array}{l}\text { BC SC, } 1997 \\
\text { SK QB, } 2001\end{array}$ \\
\hline $\begin{array}{l}\text { Court is not willing to take a } \\
\text { calculated risk }\end{array}$ & 3 & $\begin{array}{l}\text { SK QB, } 1993 \\
\text { SK PC, } 2006 \\
\text { SK QB, 2009 } \\
\end{array}$ \\
\hline $\begin{array}{l}\text { Accused does not have deep } \\
\text { roots in community }\end{array}$ & 2 & $\begin{array}{l}\text { SK QB, } 1993 \\
\text { BC SC, } 1997\end{array}$ \\
\hline $\begin{array}{l}\text { Community is not willing to } \\
\text { participate }\end{array}$ & 3 & $\begin{array}{l}\text { BC CA, } 2001 \\
\text { SK QB, } 2001 \\
\text { BC PC, } 2004 \\
\end{array}$ \\
\hline $\begin{array}{l}\text { Victim is not willing to } \\
\text { participate }\end{array}$ & 3 & $\begin{array}{l}\text { NF SC, } 1994 \\
\text { SK CA, } 2004 \\
\text { SK QB, } 2009 \\
\end{array}$ \\
\hline Other $^{120}$ & 3 & $\begin{array}{l}\text { BC SC, } 1997 \\
\text { SK QB, } 2001 \\
\text { SK QB, } 2005\end{array}$ \\
\hline
\end{tabular}

11 Joecyounon, [1995] 6 W.W.R. 138 (domonetrating Judge Fafard'o critoria and factore wore delineated by Judge Grotsky in R. v. Cheekinew (1993), 108 Sask. R. 114 (Can. Sask. Q.B.), but it doco not include Fafard's factors regarding whether the facts were agreed upon and whether the accused agroed to bo reforrod to a sentencing circle, as thero wore no cases that were denicd for these reasons. $\Lambda$ moro appropriato or accurate way to doal with iseuos involving the accusod is to query whother the accuaod sufficiontly accopted rosponsibility for hio or hor actiono before involving the victim and the community in a joint process).

119 Court of Appeal ("CA") and Superior Court ("SC") are higher-level courts with federally appointed judges, and Provincial Court (" $\mathrm{PC}$ "), is a lower level trial court with provincially appointed judges.

120 Other reasono for donying a request for a sentencing cirole includod: concorn that the discuseion was going to be outside the normal scope of oentencing circles and about the charge rather than about the accused, see R. v. Stick (C.) (2001), 202 Sask. R. 306 (Can. Sask. Q.B.); concern that it was not appropriate to sever sentencing processes, see Pena (M.J.), 148 D.L.R. 1th 372; and, concern that the victims were numerouo and the community was divided in support or anger of the multiple accused, see R. v. Gopher (2005), 270 Sask. R. 175 (Can. Sask. Q.B.). 
Judges across each province apply tests or criteria to determine whether a sentencing circle is appropriate in a particular case. ${ }^{121}$ The list of factors for the tests or criteria were developed and modified as individual judges referred to similar judicial action in other provinces. ${ }^{122}$ It should also be noted that in the Newfoundland and Labrador case referred to above, ${ }^{123}$ the Court of Appeal went out of its way to identify that the trial judge's mistake was not the decision to allow a sentencing circlo, rather, the judge failod to consider whether the relevant criteria was met. ${ }^{124}$ The appellate court concluded that the trial judge erred:

not because he used a sentencing circle. (That may or may not have been an appropriate decision in the exercise of his discretion.) He did so, rather, because there were relevant factors that he should have considered, but that he did not (or, at least, there is no record of his ever having considered them). ${ }^{125}$

\section{Sentencing Circle Recommendations}

Once the trial judge allows a sentencing circle, the court will adjourn for a period of time to allow for necessary preparations. ${ }^{126}$ Participants who

\footnotetext{
${ }^{121}$ Judges in Yulron, Ontario, and Alberta considorod similar critorin to those laid out by judgeo from Saskatchewan, British Columbia, Newfoundland and Labrador. See supra notes 114-120; see, e.g., R. v. Manyfingers (C..J.) (1996), 191 A.R. 342. paras. 125-27 (Can. Alta. P.C.) (reviewing the Soskatchoman and Rritish Cnlumbia teste and holding that "[n]n matter what procedure is followed, it must be based on high logal standards"); R. v. L. (B.) (2002), 296 W.A.C. 78, paras. 7, 39.53 (Can. Nlta. C. A.) (finding that the trial judge erred by not dealing with disputed facts as to the extent of the defendant'o involvement in the crime prior to conducting the sentencing circle; and noting that (i) there were no members of the community present that were not rolated to the dccused, and (ii) the victim's wife, who was the victim of the crime, was nut presnet because of

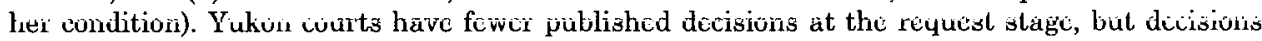
on oentencing indicate that the court considered: the defondent's voluntary participation; cummunity support; participation of the victim; and the defendant's acceptance of responsibility See R. v. Van Bibber, [2010] Y.K.T.C. 49, para. 78 (Can.); R. v. Craft, [2006] Y.K.T.C. 19, para. 31 (Can.).

122 See supra notes 114-118.

${ }^{123}$ See R. v. J. (J.) (2004), 244 Nfld. \& P.E.I.R. 24, para. 1 (Can. Nfld. \& Lab. C.A.).

124 Specifically; the court pointe to the following critoria "to be uoed in deciding whether or not a sentencing circle should be used: (1) Willingness and Suitability of the Convicted Person . . . (2) Willingness of the Victim (Freely Given) . . . (3) Willingness of the Community to Participate ... [and] (1) Whether the Offence Required a Tcrm of Imprisonment." Id. I 73. The court held that the judgo failed to adoquately consider three of those four critoria. $I d$.
}

${ }^{125}$ Id. 974.

126 See, e.g., R. v. Morris, [2004] B.C.W.L.D. 807, paras. 1, 25 (Can. B.C.C.A.) (reporting that the defendant pled guilty on July 22, 2003, and the sentencing circle was held on February 13, 2004); R. v. Nicholas (B.L.) (1996), 177 N.B.R. 2d 124 , paras. 1-3 (Can. N.B.P.C.) (reporting that the defendant pled guilty on January 8,1996 , and tho sentoncing circle was held on March 25, 1996); R. v. Pauchay (2009), 328 Sask. R. 173 (Can. Sask. P.C.); R. v. Pauchay (2009), 333 Sask. R. 167 
normally appear during the sentencing phase of the trial, including the defendant, defense counsel, the Crown, the police, social workers, and the judge, also participate in the sentencing circle. ${ }^{127}$ Additionally, the victim and members of his or her family, as well as members of the defendant's family and other members of the community will also be present. ${ }^{128}$ Talking about the crime and its impact is meant to be an educational experience, where the defendant learns about why and how his or her actions had a negative impact. ${ }^{129}$ It is also an opportunity for participants to discuss larger socioeconomic issues facing the community. ${ }^{130}$ At the conclusion, the circle will present recommendations for sentencing to the judge. ${ }^{131}$ The court adjourns for final submissions, and then the judge delivers the sentence.

(Can. Sask. P.C.) (atating that the request for the sentencing circle was grantod on January 7 , 2009, the circle was held on February 13, 2009, and the Crown and defense counsel made final submissions on sentenring on Marrh 4, 2009); R. v. Kahypeasewat, (2006), 284 Sask R. 55 (Can Sask. P.C.) ("The accused plead guilty to manslaughter on September 26, 2005. In May 2006, a sentencing circle was held."). Pre oentencing reports are aloo propared in the intorim. But soc R. v. Johns (J.C.), [1995] B.C.W.L.D. 2996 (Can. Y.K.C.A.) (stating that preparations for the sentencing circle were done before the conviction phace and that "[b]y tho time Mr. Johno attended court to plead guilty and to be senteneed, he had completed a 30 day residential alcohol treatment program in Cardston, Alberta and had been sober for eight months.").

197 STUART, supra note 19, at 48-51 (discuocing the role of court perconnel beforo and during tho sentencing circle); Lilles, supra note 20, at 81-82 (noting that at the beginning of the proceedings the charges are read, and Crown and defense counsel will make brief opening statements).

128 , Sep, e g., R. v. Craft, [2กnG] Y K T R. 19, para. 33 (Can) (nnting that the sentencing circle "was conducted on two oeparate days. Thirty people were prosent on the first day, Fobruary 6, 2006, including threc of the victims in the car driven by Jodic MacMillan, hor fathor and the parents of the third person, Ainslinn Cornett. $\Lambda$ number of their close friende were also in the Circlo supporting them. Twenty people were in the Circle on the second day, April 19, 2006, including the victims and/or their family members."); R. v. Poker (2006), 261 Nfld. \& P.E.I.R., para. 54 (Can. Nfld. \& Lab. T.D.) ("There were twenty participants in tho circle which was under tho direction of Mr. Apenam Pone as the Circle Keeper and a well-respected Innu man in his own right as counsellor for the Innu people of Sheshatshiu."); see also Lilles, supra note 20, at 81 (estimating that between fifteen and fifty people usually attend the sentencing circle); STUART, supra note 19 , at 45 (discussing the importance of pre-circle preparation).

${ }^{129}$ Lilles, supra note 20, at 84; STUART, supra note 19, at 9, 86 ("All the circumstances of the offender, victim, and offence are examined to understand the underlying causes of the crime in order to appreciate what relationships must be healed and strengthened - and called upon in developing a healing plan.").

130 See, e.g., Craft, [2006] Y.K.T.C. 19, para. 35 (stating that participants discussed "the frcquency of drinling and driving in the Yulson and how peoplo driving to and from work are at risk."); R. v. Kahypeasewat, 281 Sask. R., I 62 (noting that the circlo diocusood "tho dynamic of the offence"); Lilles, supra note 20 , at 81 (otating that topics at a sentencing circle often include: " $[t]$ he extent of similar crimes within the community; [ $t$ ] he underlying cause of such crimes; [a] rotrospective analysie of what life in the community had been hefore crime herame an pravalent; [t]he impact of these sorts of crimes on victims generally, on families and community life ....") (ellipses removed).

${ }_{131}$ See, e.g., R. v. J. (J.) (2004), 244 Nfld. \& P.E.I.R. 24, para. 2 (Can. Nfld. \& Lab. C.A.) ("It was the recommendation of the Sentencing Circle that Mr. Poker be permitted to serve whatever is left of his sentence in the Community of Natuashioh under the direction of the councellors there . . and with the help of the clders that they would offer whatever assistance they could to get Mr. 
It is important to analyze how judges treat sentencing circle recommendations in the final sentencing decision. With respect to the cases discussed in this Article, judges accepted the recommendations of sentencing circles in eighteen of the thirty-seven reported cases. ${ }^{132}$ However, in seven of those cases, the Crown successfully reversed the sentence on appeal. ${ }^{133}$ The table below shows the number of sentencing circle recommendations from 1992 to 2010. During this span, trial judges accepted recommendations in eighteen cases and explicitly rejected them in seven cases.

Poker back on track again.”); R. v. Taylor (1995), 132 Sask. R. 221, para. 1 (Can. Sask. Q.B.) (ruting that the "consensus" of the community paiticipants "was that Taylor shuuld be banislied to an ioland for the period of one year and if he completes this period of baniohment then he chould be put on probation for three years with conditions that he attend a program on acxual abues, anger managemont and alcoholiom and that he would not have contact with the victim for a poriod of throe ycare from the commenecment of the probation); R. v. Paul (D.) (1098), 203 N.B.R. 2d 243, para. 15 (Can. N.B.P.C.) (noting that the court delivered the sentence, after considering "all relevant principles and the concerns and recommendations of the circle," which included banishment); R. v. Elliot, [2006] A.B.P.C. 372, para. 34 (Can. Alta. P.C.) (noting that the sentencing circle recommendations "were presented to the court to assist the court in sentencing."). But see R. v. Morris, [2004] B.C.W.L.D. 807, paras. 25, 75-76 (Can. B.C.C.A) (noting that because of the victim's concerno, "the circle proceded more as a broad discussion of themos than for the opecific purpose of formulating recommendations for sentencing . . . . But, the court later notoo that the trial judge'o eonditions for probation; namely 'hosting a potlatch; organizing a Man's Talking and Sharing Circle; and completing the community service hours ... parallel the recommondations which omorgod from the talking circle held on 13 February 2001 .. .."); Kahypeasewat, 284 Sask. R. 55, para. 62 (stating that participants at the sentencing circle "wore givon an opportunity to provide input into sentencing options").

${ }^{132}$ See infra Appendix B for cases where sentencing circles were held, by casc, ycar, and court.

133 In total, the Crown appealed over one third of the cases-seventeen out of forty-seven-in which sentencing circles wero roquestod or hold. Dofenso council appealed only one out of eighteen circle sentences. Moreover, the Crown succeeded in thirteen of its seventeen appeals. 
Table 3: Did the Judge Accept the Sentencing Circle's Recommendations?

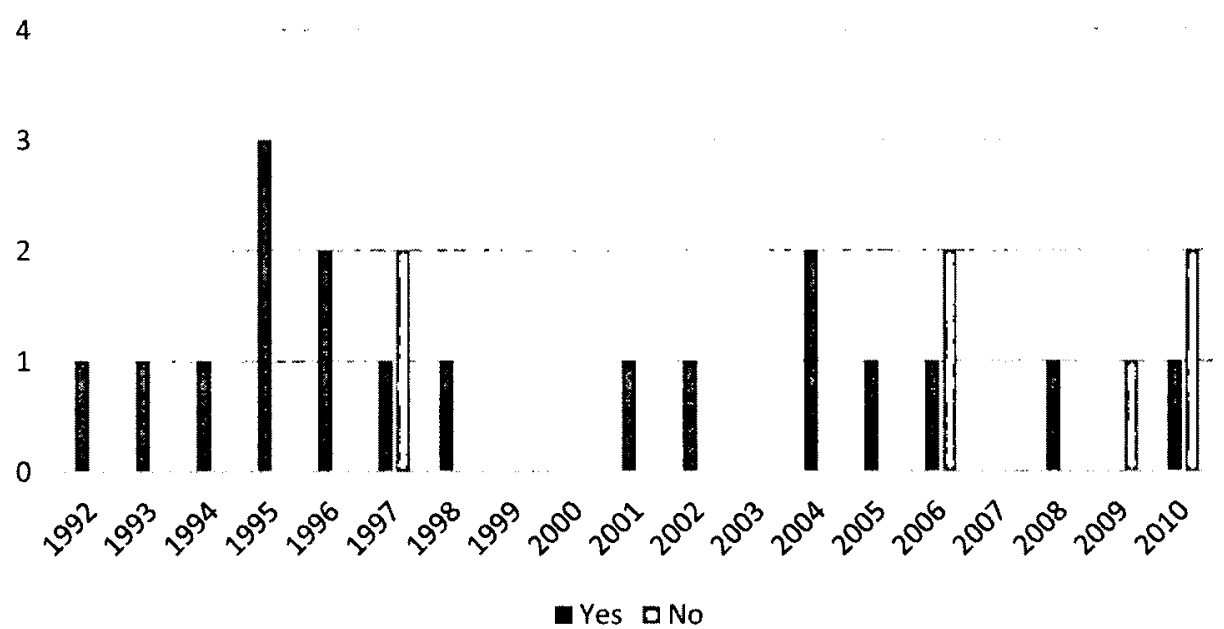

A troubling statistic remains that the status in twelve of the thirty-seven cases in which sentencing circles were held and rocommondations given are unknown. In these twelve decisions, the trial judge neither specified the nature of the recommendations made by the sentencing circle participants, nor whether the recommendations were followed. In some cases, the judge did impose a conditional sentence, which may indicate that the judge accepted the circle's recommendations, ${ }^{134}$ although such acceptance is impossible to confirm. The chart below revises the data in Table 3 to include decisions that do not discuss the specific recommendations made by sentencing circle participants.

Table 4: Did the Judge Accept the Sentencing Circle's Recommendations [Revised]?

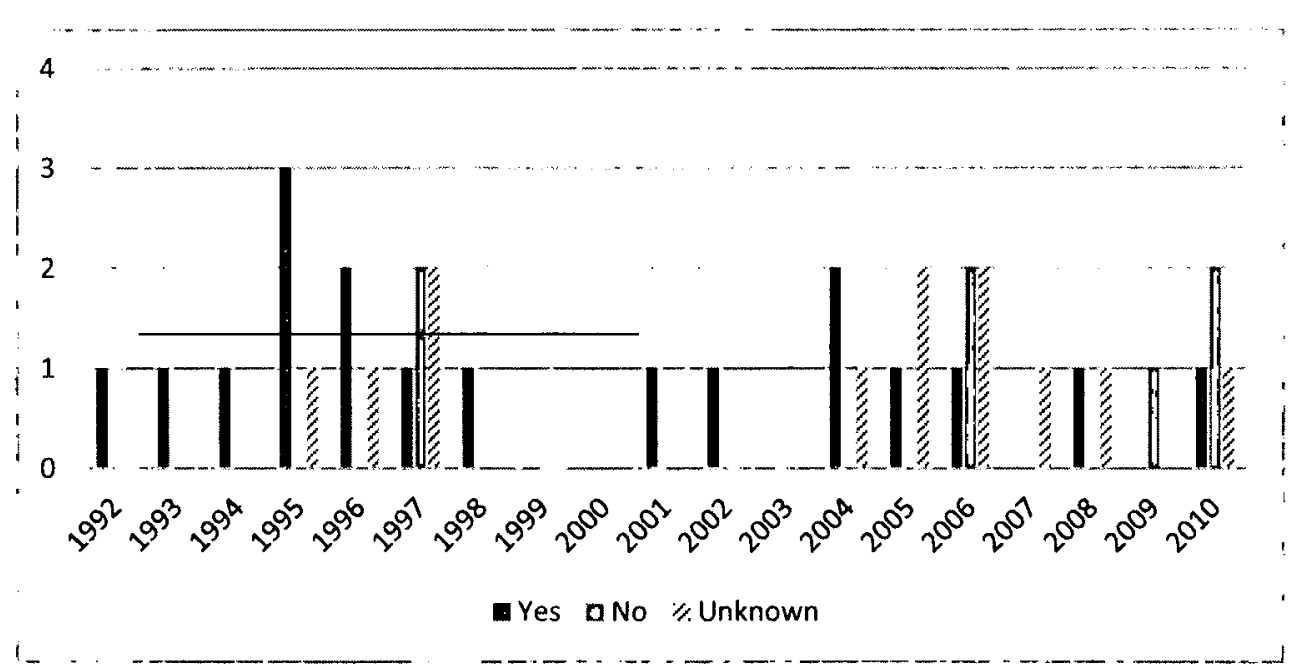


Canadian criminal procedure does not require judges to disclose the details of pre-sentencing information in their sentencing decisions. ${ }^{135}$ Consequently, in the twelve cases where the trial judge did not note the details of the recommendations, the judge may have treated sentencing circle recommendations in the same manner as other pre-sentencing information. ${ }^{136}$ On the other hand, there were several instances where judges treated sentencing circle recommendations quite differently from presentencing reports or information. ${ }^{137}$ For example, in $R$. $v$. Labelle (B.), the judge dealt with the sentencing circle recommendations as if they were part of a negotiated agreement that would become valid once endorsed by the court. ${ }^{138}$

\section{DISCUSSION}

\section{A. Debates in Comparative Law}

In Part III we saw that there was a transplant effect, especially at the final sentencing stage, where judges were unsure what to do with sentencing circle recommendations. ${ }^{139}$ Why does this matter? How is this case different from any other logal problem where there is a transplant effect? This $\Lambda$ rticle proposes that there is a difference when the transplant is undertaken not only because it represents best practices, but also because those best practices represent cultural and humanistic goals. Furthermore, this Article argues that there are increased risks when normative and cultural expressions are instrumentalized. This occurs when the expressive genre of law, which attempts to reflect the world, is used as an instrument, ${ }^{140}$ and, when this happens, its implementation, outcomes, and transplant effects must be examined.

To examine the instrumental value of sentencing circles within the Aboriginal culture it is important to evaluate scholarship in comparative law. Wigmore, a legal scholar in the area, defines comparative law as "the tracing

135 Canada Criminal Code, R.S.C. 1985, c C-46 ss 721-726.2 (Can.).

136 In fact, in some decisions, the judge expressly likened the circle's recommendations to information or reporto; which are submitted to the court at, or prior, to sentencing. See, e.g., $\mathrm{R}$. v. Naappaluk (1993), 25 C.R. 4th 220 (Can. C.Q.); R. v. Brooks (2008), 331 N.B.R. 2d 268, paras. 9 11 (N.B.C.A.); R. v. Craft, [2006] Y.K.T.C. 19, para. 13 (Can.) (noting in an opinion written by Judge Heino Lillee regarding the sentencing circle as comparable to a victim impact statement).

${ }_{137}$ In the same case where he compared the sentencing circle process to a victim impact statement, Judge Lilles' remarks seemed to imply that the sentencing circle was actually deliberating on an appropriate sentence. See Craft, [2006] Y.K.T.C. 19, para. 61. That decision reads more like a judicial review than a distinet oentoncinfs process.

138 R. v. L. (B.) (2002), 266 W.A.C. 78, (Can. Alta. C.A.).

139 Berkowitz et al., supra note 6, at 175-76.

140 Taking on the Technicalities, supra note 12, at 1027-28. 
of an identical or similar idea or institution through all or many [legal] systems, with a view to discovering its differences and likenesses in various systems, the reasons for those variations, and the nature and limits of the inherent and invariable idea ...."141 However, Wigmore does not ask to what objective are comparisons made - to acquire a body of knowledge or map legal traditions? 142. What exactly do we compare when we engage in an exercise of comparative law? ${ }^{143}$

Comparative law scholars compare legal systems that face the same, universal problems. ${ }^{144}$ Konrad Zweigert and Hein Kotz wrote that the purpose of comparative investigations is always functional and instrumental, ${ }^{145}$ while particular legal institutions and different laws are meant to solve social problems that are similar among these institution. ${ }^{146}$ Thus, comparative law allows scholars to discover the best practices, of both legal rules and institutions, which one legal system can transplant to another. ${ }^{147}$ Comparative law scholars also consider functionality when deciding which laws to compare because, "incomparables" cannot productively be contrasted while "those which fulfill the same function" can be. ${ }^{148}$

According to these "social purpose functionalists," 149 functionally equivalent legal institutions are transported between legal systems for their improvement. The view that imported legal institutions address social, economic, or political goals is solidly entrenched in a broader history of thinking that views law as a tool and society as a site that needs fixing. ${ }^{150}$

141 John H. Wigmore, Comparatine Imw: Jnttings on Compratiue Iegal Ideas and Institutions, $\mathrm{f}$ TUL. L. REV. 48, 51 (1932).

142 Mathias Reimann, The Progress and Failure of Comparative Law in the Second Half of the Twentieth Century, 50 AM. J. CoMP. L. 671, 673-77 (2002).

${ }^{143} I d$. at 686.

144 Ralf Michaels, The Functional Method of Comparative Law, in THE OxFond HANDBOOK OF COMPARATIVE LAW 339, 356-58 (Mathias Reimann \& Reinhard Zimmermann eds., 2006) (referring to the idea that "cimilar functional needs can be fulfilled by different institutions", and noting that "the recognition of functional equivalento gave a boost to the possibilities for comparative law," which the author refers to as "Equivalence Functionalism").

145 ZWEIGERT \& KÖETZ, supra note 9, at 34.

146 Nils Jansen, Comparative Law and Comparative Knowledge, in THE OXFORD HANDBOOK OF COMPARATIVE LAW 305, 323-338 (Mathias Reimann \& Reinhard Zimmermann eds., 2006).

${ }^{147}$ Hill, supra note 5 , at 109.

148 ZWEIGERT \& KöETZ, supra note 9.

149 Fornanda G. Nicola, Family Law Exceptionalism in Comparative Law, 58 AM. J. CoMP. L. 777 , 794 (2010).

150 RUdOLF VON IHERING, LAW AS A MEANS TO AN END (Isaac Husic trans., 1914); BRIAN Z. TAMANAHA, A GENERAL JURISPRUDENCE OF LAW AND SOCIETY (2001); SUMMERS, supra note 12. Legal scholars in the late 19th and early 20 th Centurios who criticized the formaliat approach to 
"Legal instrumentalism"-the idea of law as a tool or a means to an end-is currently at the center of American legal thinking. ${ }^{151}$ In many ways, law's instrumentality is also what makes it interesting as an object of study. ${ }^{152}$ Those who derogate from the law as a tool axiom appear to challenge a whole ontology of law. 153

The "culturalists" could be said to constitute a second group of comparativists. ${ }^{154}$ These scholars hold to the Savigny/Montesqui idea of l'Esprit de loi ${ }^{155}$ - that positive law is the spirit of the people. ${ }^{156}$ In this group, scholars are less sanguine about the possibilities of transplanting whole legal rules or institutions. These scholars believe that law is part of a cognition or culture $^{157}$ that societies accept ${ }^{158}$ or translate. ${ }^{159}$ Thus, societies cannot transport best practices. ${ }^{160}$ Scholarship among this group ranges in a

judicial docicion malking argued in favor of a pragmatic and sociological judicial process; law is a tochnology that lawmalroro as cociological cngineers employ to achicve their goals. See Malcolm M. Feeley, Three Voices of Socio-Legal Studies, 35 ISR. L. REV. 175 (2001). Scholars may disagroo about which goals to pursue or which wayo to puroue them, but they can gencrally agree that law is a means to an end. See generally BRIAN Z. TAMANAHA, THE PERLS OF PERVASIVE LEGAL INSTRUMENTALISM (2006).

151 TAMANAHA, supra note 150; SUMmERS, supra note 12, at 179.

15? Law us Objecl, supra nole 13, The Materiality of Whit? supra note 31.

${ }_{153}$ It may be for this reason that there is not as much a conversation about legal instrumentaliam as thore aro rumblinge of diasatiofaction and disorientation in the form of isolated aclf reflections about the failure of particular projects. See Kevin E. Davis \& Michael J. Trebilcock, The Relationship Between Law and Development: Optimists Versus Skeptics, 56 AM. J. CoMP. L. 895 (2008); David M. Trubek \& Marc Galanter, Scholars in Self-Estrangement: Some Reflections on the Crisis in Law and Devclopment Studico in the United States, 1 WIE. L. REV. 1062 (1971); Merryman, supra note 1; Robert Dingwall, A Stranger at the Table: Reflections on Law, Society, and the Higgs Boson, 36 LAW \& SOC'Y REV. 29 (2002). For complaints about discrepancies botwoon law on the books and law in action, see Feeley, supra note 150.

154 Taking on the Technicalities, supra note 12, at 106; Roger Cotterrell, Comparative Law and Legal Culture, in THE OXFORD HANDBOOK OF COMPARATIVE LAW 709, 710-11 (Mathias Reimann \& Reinhard Zimmermann eds., 2006).

155 Duncan Kennedy, Savigny's Family/Patrimony Distinction and its Place in the Global Genealogy of Classical Legal Thought, 58 AM. J. COMP. L. 811, 811 (2010); Nicola, supra note 149.

156 Wigmore, supra note 141 , at 51 (". . . a legal institution can be fully comprehended only in the light of the social, economic, religious, political, racial, and climatic circumstances which surround it.").

${ }^{157}$ Louis F. del Duca \& Alain A. Levasseur, Impact of Legal Culture and Legal Transplants on the Evolution of the U.S. Legal System, 58 AM. J. COMP. L. 1 (2010).

158 Langer, supra note 8; see also Gianmaria Ajani, By Chance and Prcatigc: LcEal Transplants in Russia and Eastern Europe, 43 AM. J. COMP. L. 93 (1995).

159 Berkowitz et al., supra note 6; see also JAMES A. GARDNER, LEGAL IMPERIALISM: AMERICAN LAWYERS AND FOREIGN AID IN LATIN AMERICA 8-9 (1980) (discussing the unsuccessful attempts to transplant and develop U.S. legal frameworks in developing countries due to a lack of understanding "local language, law, polity, economy, or culture").

${ }^{160}$ Pistor, supra note 5 . 
spectrum from weak cultural theorists, who believe that legal institutions transfer between legal families, ${ }^{161}$ to strong theorists, like Legrand who argue that because national or local culture determines the nature and specifics of legal institutions, it never make senses to talk about legal transplants. ${ }^{162}$ In comparative law and scholarship on legal transplants, this could be referred to as the "does culture matter" 163 debate.

\section{B. Objectification of Legal Knowledge}

The commissions and task forces that investigated Aboriginal confrontation within the criminal justice system were clearly situated on the culture side of this debate. Aboriginal justice advocates saw conceptions of justice as "integrally related to that society's world views and life philosophies." ${ }^{64}$ Reports noted vast differences between Euró-Canadian and Aboriginal approaches to righting legal wrongs-Aboriginal approaches sought restoration and healing, whereas Euro-Canadian criminal justice sought deterrence and punishment. ${ }^{165}$ This conflict between two sets of justice values produced feelings of alienation and contributed to overincarceration of Aboriginal offenders. ${ }^{166}$ Culture mattered.

On the other hand; the exercise in comparative law comparing Euro Canadian and Aboriginal approaches to justice-was instrumental. Researchers sought to show how traditional Aboriginal healing circles and the sentencing phase of the criminal trial were functionally similar, addressing the same social problem: crime in the community. Comparing Euro-Canadian and Aboriginal approaches had a purpose. It was an effort to look at "foreign" law to assist with a criminal law "domestic" reform project. ${ }^{167}$ Aboriginals' feelings of alienation and negative experiences originated in the incompatibility between two justice systems and worldviewe, ${ }^{168}$ but ultimately the source of the problem-that law and eulture

${ }^{161}$ See generally The Common CORE of European Private Law, supra note 6.

162 Soe Legrand, eupra noto 34, at 122; see also Pierro Logrand, European Logal Systems Aro Not Converging, 45 INT'L \& COMP. L. Q. 52, 81 (1996).

${ }_{163}$ See generally Amartya Sen, How Does Culture Matter?, in CULTURE AND PUBLIC ACTION 3758 (Vijayendra Rao \& Michael Walton eds., 2004).

164 HAMILTON \& SINCLAIR, supra note 52, at 59. Individual scholars were coming to similar conclusions. See, e.g., RosS, supra note 44; FRIDERES \& GADACZ, supra note 44; DIVERSITY AND JUSTICE IN CANADA (Douglas E. King \& John Winterdyk eds., 1999); Ross Gordon GREEN, JUSTICE IN ABORIGINAL COMMUNITIES: SENTENCING ALTERNATIVES (1998).

165 See DuMONT, supra note 50; Mandamin, supra note 58; see also ROYAL COMMISSION ON Aboriginal PeOPLES, 1 RePort of THE RoYAl CoMmission ON ABORIGINAL PEOPLES: LoOKING FORWARD LOOKING BACK 218 (1996); Ross, supra note 44; FRIDERES \& GADACZ, supra note 44.

${ }^{166}$ See DUMONT, supra note 50, at 30-32; Giokas, supra note 16, at 187.

167 See Dubber, supra note 28, at 435-36.

168 See Goldbach et al., supra note 8, at 19. 
were intertwined-could also provide the solution. Those conceptions of justice, integrally interwoven with worldviews, could be used as a tool to address over-incarceration and the negative experience of Aboriginal offenders. Aboriginal justice so clearly provided a solution, that in 1996 Robert Depew wrote, "[p]erhaps more than any other expanding alternativesto-the-State movement in Canada, 'popular justice' for [A]boriginal communilies has been embraced by its advocates as a solution to a range of unique justice problems faced by [A]boriginal communities."169

Ralf Michaels argues that scholars often over-estimate the possibility that legal systems will converge by ignoring entrenched legal paradigms, for example, in determining jurisdiction for private law matters. ${ }^{170} \mathrm{~A}$ similar problem exists here, as law reformers sought to harmonize alternative dispute resolution methods with Aboriginal justice approaches. Those scholars and practitioners, who advocated adapting Aboriginal methode for dealing with harm to the community, were optimistic 171 about the possibilities of transplantation when the "origin" and "host" legal systems had contrasting and entrenched legal paradigms. ${ }^{172}$

This case study, however, represents more than merely an example of harmonizing systems with entrenched legal paradigms or transplanting legal institutions into unreceptive legal systems. ${ }^{173}$ In addition, these transplanted sentencing circles are an example of instrumentalizing the expressive. Scholars, practitioners, and reformers articulated the legal expression of Aboriginal culture. They conveyed the meaning of Aboriginal justice as a way to identify that group and its particular concerns, ${ }^{174}$ and then turned that meaning back on itself in order to serve a useful function.

Sentencing circles represent both kinds of objectification of legal knowledge: they are a reflection of Aboriginal culture, and they are a "thing in the world"175_-a process that takes place at the sentencing phase of the criminal trial. Here, though, the two genres of legal acts ${ }^{176}$ - the expressive and instrumental genres-are integrated and conflated. The fact that sentencing circles could sorve as an idontifier of Aboriginal culture and stand

169 Robert C. Depew, Popular Justice and Aboriginal Communities: Some Preliminary Considerations, 36 J. LEGAL PLURALISM \& UNOFFICIAL L. 21, 22 (1996).

${ }^{170}$ Ralf Michaels, Two Paradigms of Jurisdiction, 27 MICH. J. INT'L L. 1003, 1047-48 (2006).

171 See Merryman, supra note 1; Davis \& Trebilcock, supra note 154.

172 Goldbach et al., supra note 8.

173 See Berkowitz et al., supra note 6.

${ }^{174}$ Law as Object, supra note 13, at 192.

175 Id. at 190.

176 See generally id. 
in for traditional healing circles in the Euro-Canadian trial was instrumental to the reformers' goals.

Of course, overlap and intermingling of the instrumental and the expressive in lawmaking is not unique to this Canadian case study. This arises when law and development literature points to rule of law or democratic freedom as the key to progress, ${ }^{177}$ when state department programs link gender equality indicators with national security, ${ }^{178}$ or when scholars point to constitutionalism as an organizing concept or archetype in legal thought.179 Canada's reform of criminal sentencing procedures, however, stands as a particularly poignant example of this movement toward cultural and normative goals. It also brings to light the hazards associated with material "things in the world" and the difficulties in mixing the material with the symbolic. ${ }^{180}$ Reformers had some expectations about the transcendent aspects of sentencing circles, but sentencing circles are also concretely present. Sentencing circles are procedures in which real peopledefendants, victims, and community members-participate.

\section{Introducing Legal Techniques}

177 See, e.s., Santos, oupra note 36; Amartya Sen, Elements of a Theory of Human Rights, 32 PIIL: \& PUB. AFr: 315,31518 (2001); Kerry Rittich, The Future of Law and Dovolopment: Second Generation Reforms and the Incorporation of the Social, 26 MiCH. J. INT'L L. 199, 202-03 (2001) "at least at the rhetorical lovel, social isoues have now been accopted both as ends of development in and of themcelves and as important factors to the achievement of general economie growth. Ao a result; issues ranging from human rights to gender equality no longer stand outside the development agenda, nor is their importance to economic development still serinusly dehated."); Daniel M. Rrinks et al., Sacial Rights Constitutinnnlism: Negotiating the Tension Between the Universal and the Particular, 11 ANN. REV. L. \& Soc. SCI. 289, 290-91 (2015) (examining "the increasing inclusion of social and economic rights language in constitutions" and noting "the remarkable diffusion of cocial rights into constitutions around the world over the past fifty or sixty years"). See also discussion supra note 15 (examining the overlap in instrumental and normative goals).

178 See, e.g., Annelise Riles, Smart Power: Feminism and Instrumentalism in US Foreign Policy (2013) (unpublished paper presented at the Public International Taw Workshop, Iondon Srhool of Economics ) (on file with the author).

179 See, e.g., David Kennedy, The Mystery of Global Governance, in RuLING THE WoRLD?: CONSTITUTIONALISM, INTERNATIONAL LAW, AND GLOBAL GOVERNANCE 37, 37-38 (Jeffrey L. Dunoff \& Joel P. Trachtman eds., 2000) ("In tho past fow years, many havo exporimonted with the metaphor of a constitution to describe the legal order beyond the nation-state .... Others have soen a constitutional moment in the emergence of humüi riglit as as a glubal veraaculai fü' the legitimacy of powor . . . Comparative constitutional law is front and conter in their accounts of how we are governed at the global level."). Duncan Kennedy, Three Globalizations of Law and Legal Thought: 1850-2000, in THE NEW LAW AND ECONOMIC DEVELOPMENT: A CRITICAL APPRAISAL 1973 (David M. Trubek \& Alvaro Santos ods., 2006); Rodríguez Caravito, supra note 36.

180 See generally WEBB KEANE, Signs of RECOGNITION: POWERS AND HAZARDS OF REPRESENTATION IN AN INDONESIAN SOCIETY 23-28 (1997) (by means of an ethnography of ritual opeech in Anakalang, diøousging the "social foree of signs" and their potential for failure because symbols are at once both representations and material things). 
When reviewing the judicial decisions it became evident that - unlike the instances of judges responding to sentencing circle requests with a list of factors to consider judges did not develop common law directive tools to assist in proccscing scntencing circle recommendations. When a sentencing circle was requested, judges limited their discretion by creating tests and identifying criteria that had to be considered. By comparison, at the final stage of crafting the sentence, judges treated the sentencing circle rocommendations inconsistently and without disciplined legal techniques.

Several judges did not give an account of the sentencing circle recommendations for the record. ${ }^{181}$ Sometimes judges compared the recommendations to pre sentonce reports or victim impact statemonts, and at other times judges seemed to approach the recommendations as if they were a negotiated settlement. There were no tests, factors, or technical practices that judges implemented to decide whether or not to include sentencing circle recommendations into the final sentence. At this second stage-after the sentencing circle has been conducted-judges were left without legal techniques and technologies to assist in processing the information, in woighing and balancing considerations, or in dealing with legal conflicts.

At first glance, this absence of legal devices may not seem problematic. One could argue that conducting a sentencing circle allows the judge to get more information about the accused and the community's ability to help monitor conditions. Nevertheless, the final sentencing rests with the judge. While section 35(1) of the Constitution Act of 1982 recognizes Aboriginal rights and practices, ${ }^{182}$ these are not unlimited rights and must be compatible with Canadian sovereign authority. ${ }^{183}$ In other words, Canadian sovereign authority has a monopoly on sentencing and incarceration, such that the potential right to a pre-existing practice to conduct healing circles is not unfettered.

This technical legal argument is not overly persuasive in light of a technical counterargument. If the sentencing circle is merely an information gathering exercise, there is no reason to require a test to decide whether a sentencing circle can be held. If there are criteria to determine whether to allow the request for a sentencing circle, the sentencing circle is ab initiodistinct from other pre sentencing practices without tests.

\footnotetext{
181 See discussion supra note 81.

182 The Constitution Act, 1982, being Schedule B to the Canada Act, 1982, c 11 (U.K.).

183 See Mitchell v. Minister of Nat'l Revenue, [2001] 1 S.C.R. 911 (Can.) (explaining that the Supreme Court of Canada has indicated that even if an Aboriginal community had a tradition of military foreo as part of ito distinctive culture, there is no concurront right to deploy an army and that only the Canadian sovercign authơrity may mâintäin â military and usc force within its own territory).
} 
Sentencing circle recommendations may appear functionally similar to pre-sentencing reports or victim impact statements. However, focusing on the instrumental form- "the particular devices, practices, or orientations"${ }^{184}$ makes the differences apparent. The practices required to compose presentencing reports, victim impact statements, and sentencing circle recommendations differ. ${ }^{185}$ A pre-sentence report is put together by a probation officer in the course of his or her employment, usually in the form of a document with questions. ${ }^{186}$ On the other hand, sentencing circle recommendations come about through unscripted, guided discussion by varied numbers of volunteers participating and observing. The process can be lengthy and intrusive to the lives of the victims, the accused, and the community.

The level and extent of community participation in sentencing circles brings to mind jury or lay judge involvement in the legal system. ${ }^{187}$ Scholars have noted the similarities between jury participation and democracy. 188 The link between political and judicial participation also figures prominently into

${ }^{184}$ Law as Object, supra note 13, at 201; see also Pottage, supra note 31 (exploring Roman Law as a way to axamine law as a sperifir sel of tools and leshnical deviras for unking relations); ses also Collateral KNOWLEDGE, supra note 43, at 232 (arguing that legal theorists, social scientists, and policy makers need to pay more attention to legal form and legal technique in addition to the content of law and legal regulation).

185 See generally BRINO I LATOIIR \& STEVE WOOIGAR, I SCIENTIFIC FACTS 45-69 (1986) (describing the practices of lahorgtory srientists which "inscrihe" material substances into diagrammatic form, focusing on tho particular and variod aotivitios which produce journal articles).

186 Kolly Hannah-Moffat \& Paula Maurutto, Re Contcxtualizing Pre.Sentence Reports: Risk and Race, 12 PUNISHMENT \& SOC'Y 262, 263, 267 (2010) (noting the number of jurisdictions in Canada and the United States that are using "standardized actuarial risk assessment inatrumento," reports that focus on "objectivo' criteria (i.e. typo of offonco, prior criminal history, age and gender and sentenec length) and factoro that aro ompirically ohown to be statistically co. related with recidivism," which can be quickly scored).

187 Sce, e.g., Goldbach \& Hans, supra note 26 (cxplaining that the provisions that malic sentencing circles permissible for Aboriginal offenders address the circumstances of that population, and include the history of indigenous confrontation with colonizerc and its eurrent effects and manifeotations. It is therefore difficult to conceive of a situation where a non aboriginal community would conduct a sentencing circle); see R. v. Gladue, [1999] 1 S.C.R. 688, para. 58 (Can.); R. v. Poker (2006), 261 Nfld. \& P.E.I.R. 1 (Can. Nfld. \& Lab. T.D.) (showing that despite not taling eentencing circles out of the converoation about lay participation in criminal law, historically and presently, many jurisdictions have and do restrict the selection of juries or lay judges on the basis of socio-economic, occupational, educational or other demographic factoro); sce S. Kutnjak Ivkovi, Exploring Lay Participation in Legal DecieionMaking: Lessons from Mixed Tribunals, 40 CORNELL INT'L L. J. 429 (2007) (examining lay judges and the mixed tribunal system in Croatia); UNDERSTANDING WORLD JURY SYSTEMS THROUGH Social Psychologicnl ReSEarCh (Martin F. Kaplan \& Ana M. Martín eds, 2006) (exploring lay participation and mixed tribunals in Italy, Poland, Germany, and Japan).

188 JOHN GASTIL ET AL., THE JURY AND DEMOCRACY: How JURY DELIBERATION PROMOTES CIVIC ENGAGEMENT AND POLITICAL PARTICIPATION (2010); Valerie Hans, Introduction: Citizens as Legal Decision Makers: An International Perspective, 40 CORNELL INT'L L.J. 303 (2007). 
the Canadian reforms. ${ }^{189}$ While the government eventually disaggregated the political goals from the goal to increase Aboriginal participation in justice design and delivery, the notion of "citizen-in-justice" has always been integrated into the Aboriginal Justice Strategy mandate. ${ }^{190}$ The Aboriginal Justice Initiative and its successor, the Aboriginal Justice Strategy, could not be legitimate if Aboriginal communities did not have the right to administer justice. At the very least, the federal government has indicated its intention to delegate authority to federally-funded Community Justice Committees in a way that should make outright dismissal of sentencing circle recommendations inappropriate. ${ }^{191}$

Moreover, the 1996 amendments to the sentencing provisions in the Criminal Code were clearly meant to address a lack of expertise that sentencing scholars had previously identified. Judges were generalists without consistent application of the purposes of sentencing or principles governing legal sanctions. ${ }^{192}$ In sentencing circles, in particular, cultural and personal expertise shifts to the community. Unlike juries and lay judges, "lay" participants in sentencing circles occupy the role of experts through their knowledge of culturally appropriate procedures and often through a familiarity with the accused. ${ }^{193}$ As already noted, in many communities this expertise is constituted, institutionalized, and bureaucratized through government-funded Aboriginal Justice Committees.

\section{CONCLUSION}

Three developments reformed sentencing for Aboriginal offenders in the criminal trial, including the ad hoc way in which judges began conducting sentencing circles, the 1996 Criminal Code amendments that directed judges to consider the circumstances of Aboriginal offenders, and the establishment of the Aboriginal Justice Strategy. The examination of reported decisions reveals that transplanting Aboriginal sentencing circles into the criminal trial was neither an outright success nor failure. A "transplant effect"194 occurred with judges seemingly unsure of how to integrate sentencing circle recommendations or what was being asked of them during the final

${ }^{189}$ LaPrairie, supra note 69; see also BRDGING THE CULTURAL DIVIDE, supra note 16. Initially, the rationale for funding the $A$ boriginal Justice Initiative was to support participation in justicc administration in order to prepare communities for treaty negotiations and some mcasure of political administration. $I d$.

190ABORIGINAL JUSTICE STRATEGY EVALUATION 2011, supra note 83.

191 See discussion supra note 81.

192 CANADIAN SENTENCING CoMMISSion, supra note 68.

193 This also parallels historical accounts of juries in England who would testify to their personal knowledge of local disputes.

194 Berkowitz et al., supra note 6, at 167. 
sentencing stage. The data reveals a stark contrast between legal criteria developed at the request stage and the absence of technical legal knowledge practices at the recommendation and sentencing stage.

The history of sentencing reform in Part II describes how law reform projects constituted cultured procedures, which then became instruments reformers could use. In comparing justice principles, Aboriginal justice advocates identified an expression of Aboriginal culture as the solution to both humanistic experiential and sociological goals. I call this an instrumentalizing of the expressive, where an attempt to generate meaning was not only the end-goal, but also the tool-the "thing in the world"-to accomplish other goals that law reformers defined. ${ }^{195}$ By way of conclusion, this Article suggests that, when transforming the expressive into a tool, a technical approach might be just the thing to reveal knowledgo and enable normative goals.

Rather than excoriate the judges who were involved in these decisions, I want to appeal to the technical knowledge practices that legal intermediaries already use to mediate risk. ${ }^{196}$ Unfortunately, in American legal thinking, the technical aspects of legal knowledge practices are conflated with legal formalism as to how law does its work, and as to the opposite of what law does. Those legal thinkers who reacted against formalism did so in part because of formalism's capacity to obscure what was felt to be politically based decisions; ${ }^{197}$ for example, decisions favoring corporations over labor. On the other hand, with respect to sentencing circles, it is legal formality that established sentencing circles as a legal procedure. Through the application of tests and precedent, sentencing circles have become accescible within the criminal trial. It is where form is absent, at the stage of processing the sentencing circle's recommendations, that knowledge and politics are obscured.

In the case of sentencing circles, formalities may reveal reason. Instead of obscuring preferences, legal technicalities at the rocommondation stage may force judges to be explicit about their preferences, such as between justice theories or between expert versus "lay" decision-making in sentencing offenders. Applying technical legal knowledge practices at this stago may also be the kind of formality that facilitates, rather than hinders, desired constitutive and corrective justice goals. In the very least, some kind of technical legal practice by judges at the recommendation stage would rcinforce Aboriginal authority to administer juctice, and confer respect on the community's voice. The technical part of law, including reports, legislation, and logical legal reasoning delivered sentencing circles as a legal procedure

${ }_{195}$ Law as Object, supra note 13, at 9-11.

196 VALVERDE, supra note 29, at 192.

197 See generally SUMMERS, supra note 12. 
in the criminal trial. Where technique was absent, knowledge became obetructed and social normative goals were put in jeopardy. Especially where an expression of culturo is used as a tool, those engaged in law reform must challenge themselves to explore outcomes as evidence of unmet expectations. 


\section{Appendix A}

Request for Sentencing Circles by Case, Year, and Court

\begin{tabular}{|c|c|c|c|c|c|c|c|}
\hline & $\begin{array}{l}\text { Hit \# In } \\
\text { Search }\end{array}$ & Case Name & Year & Court & \begin{tabular}{|c} 
Crown \\
consent \\
and/or \\
request \\
not \\
reported
\end{tabular} & $\begin{array}{c}\text { Request } \\
\text { inferred } \\
\text { from } \\
\text { appellate } \\
\text { level } \\
\text { decision }\end{array}$ & $\begin{array}{l}\text { Request } \\
\text { Allowed }\end{array}$ \\
\hline 1 & 1 & R. v. Smarch & 2010 & YKTC & $\mathrm{x}$ & & $\mathrm{Y}$ \\
\hline 2 & 2 & R. v. Cooper & 2010 & Ont. CA & $\mathrm{x}$ & $\mathrm{x}$ & $\mathrm{Y}$ \\
\hline 3 & 4 & R. v. Van Bibber & 2010 & YKTC & $\mathrm{x}$ & & $\mathrm{Y}$ \\
\hline 4 & 6 & R. v. Langan & 2010 & SK PC & $\mathrm{x}$ & & $\mathrm{Y}$ \\
\hline 5 & 11 & R. v. Favel & 2009 & SK QB & & & $\mathrm{N}$ \\
\hline 6 & 14 & R. v. Pauchay & 2009 & SK PC & & & $\mathrm{Y}$ \\
\hline 7 & 17 & R. v. Brooks & 2008 & NS PC & $\mathrm{x}$ & & $\mathrm{Y}$ \\
\hline 8 & 19 & $R$. v. Stimson & 2008 & $\mathrm{AB} P \mathrm{PC}$ & $\mathrm{x}$ & & $\mathrm{Y}$ \\
\hline 9 & 24 & $\begin{array}{l}\text { R. v. } \\
\text { MacKendrick }\end{array}$ & 2007 & BC PC & $\mathbf{x}$ & & $\mathrm{Y}$ \\
\hline 10 & 25 & R. v. Elliot & 2006 & $\mathrm{AB}$ PC & $\mathbf{x}$ & & $\mathrm{Y}$ \\
\hline 11 & 26 & R. v. Braun & 2006 & BC PC & $\mathbf{x}$ & & $\mathrm{Y}$ \\
\hline 12 & 27 & R. v. Poker & 2006 & NL TD & $\mathrm{x}$ & & $\mathrm{Y}$ \\
\hline 13 & 28 & $\begin{array}{l}\text { R. v. } \\
\text { Kahypeasewat }\end{array}$ & 2006 & SK PC & $\mathbf{x}$ & & $\mathrm{Y}$ \\
\hline 14 & 30 & R. v. James & 2006 & YKTC & $\mathbf{x}$ & & $\mathrm{Y}$ \\
\hline 15 & 31 & R. v. Kinistino & 2006 & SK PC & & & $\mathrm{N}$ \\
\hline 16 & 32 & R. v. Craft & 2006 & YKTC & $\mathrm{x}$ & & $\mathrm{Y}$ \\
\hline 17 & 33 & R. v. Desnomie & 2005 & SK CA & $\mathrm{x}$ & $\mathrm{x}$ & $\mathrm{Y}$ \\
\hline 18 & 34 & R. v. Cappo & 2005 & SK CA & $\mathrm{x}$ & $\mathrm{x}$ & $\mathrm{Y}$ \\
\hline 19 & 36 & R. v. Anaquod & 2005 & SK CA & $\mathrm{x}$ & $\mathrm{x}$ & $\mathrm{Y}$ \\
\hline 20 & 37 & R. v. Gopher & 2005 & SK QB & & & $\mathrm{N}$ \\
\hline 21 & 39 & R. v. J. (J.) & 2004 & NL CA & $\mathrm{x}$ & $\mathrm{x}$ & $\mathrm{Y}$ \\
\hline
\end{tabular}




\begin{tabular}{|c|c|c|c|c|c|c|c|}
\hline 22 & 41 & R. v. Frank & 2004 & SK CA & $\mathbf{x}$ & & $\mathrm{N}$ \\
\hline 23 & 44 & R. v. Mackinaw & 2004 & BC PC & $\mathrm{x}$ & & $\mathrm{N}$ \\
\hline 24 & 46 & R. v. Morris* & 2004 & BC PC & $\mathrm{x}$ & & $\mathrm{Y}$ \\
\hline 25 & 47 & R. v. Joyea & 2004 & SK CA & $\mathrm{x}$ & $\mathbf{x}$ & $\mathrm{Y}$ \\
\hline 26 & 54 & R. v. $L .(B)$. & 2002 & $\mathrm{AB} \mathrm{CA}$ & $x$ & $\mathrm{x}$ & $\mathbf{Y}$ \\
\hline 27 & 55 & R. v. Munson & 2001 & SK QB & & & $\mathrm{N}$ \\
\hline 28 & 56 & $R$. v. Haines & 2001 & BCCA & $\mathrm{x}$ & $\mathbf{x}$ & $\mathrm{N}$ \\
\hline 29 & 58 & R. v. $K(N . T)$. & 2001 & SK CA & $\mathbf{x}$ & $\mathrm{x}$ & $\mathrm{Y}$ \\
\hline 30 & 59 & R. v. Stick $(C .)^{* *}$ & 2001 & SK QB & & & $\mathrm{N}$ \\
\hline 31 & 72 & R. v. Paul (D.) & 1998 & NB PC & $\mathbf{x}$ & & $\mathrm{Y}$ \\
\hline 32 & 79 & R. v. C. (H.K.) & 1997 & SK CA & & & $\mathrm{Y}$ \\
\hline 33 & 81 & R. v.R. (H.) & 1997 & $\mathrm{AB} \mathrm{PC}$ & $\mathrm{x}$ & & $\mathrm{Y}$ \\
\hline 34 & 83 & R. v. Pena (M.J.) & 1997 & BC SC & & & $\mathrm{N}$ \\
\hline 35 & 84 & $\begin{array}{l}\text { R. v. McKay } \\
\text { (R.W.) }\end{array}$ & 1997 & $A B P C$ & $x$ & & $\mathrm{Y}$ \\
\hline 36 & 86 & $\begin{array}{l}\text { R. v. McDonald } \\
\text { (D.P.) }\end{array}$ & 1997 & SK CA & $\mathrm{x}$ & $\mathrm{x}$ & $\mathrm{Y}$ \\
\hline 37 & 87 & $\begin{array}{l}R . v . \\
\text { Manyfingers } \\
\text { (C.J.) }\end{array}$ & 1996 & AB PC & $x$ & & $\mathrm{Y}$ \\
\hline 38 & 89 & $\begin{array}{l}\text { R. v. Nicholas } \\
\text { (B.L.) }\end{array}$ & 1996 & NB PC & & & $\mathrm{Y}$ \\
\hline 39 & 90 & $\begin{array}{l}\text { R. v. Severight } \\
\text { (A.D.) }\end{array}$ & 1996 & SK CA & $\mathrm{x}$ & $\mathbf{x}$ & $\mathrm{Y}$ \\
\hline 40 & 93 & R. v. Johns (J.C.) & 1995 & YK CA & $\mathrm{x}$ & $\mathrm{x}$ & $\mathrm{Y}$ \\
\hline 41 & 95 & $\begin{array}{l}\text { R. v. Taylor } \\
\text { (W.B.) }\end{array}$ & 1995 & SK QB & $\mathbf{x}$ & & $\mathrm{Y}$ \\
\hline 42 & 96 & R. v. John (R.C.) & 1995 & $\mathrm{AB} \mathrm{CA}$ & $\mathrm{x}$ & $\mathbf{x}$ & $\mathrm{Y}$ \\
\hline 43 & 98 & R. v. Rope & 1994 & SK QB & & & $\mathrm{Y}$ \\
\hline
\end{tabular}

- R. v. Morrie: the docision refers to a "talling circle" and the judge and Crown were not preaent; however the judge treated the procedure like a sentencing circle and accepted the recommendations.

* R. v. Stick: the reported case is an order to set aside decision denying application for holding a sontencing circle, reviewing judgo rcmanded case back to trial judge to hcar submissions about whether or not to hold a sentencing circle. 


\begin{tabular}{|c|c|l|c|l|c|c|c|}
\hline 44 & 99 & $\begin{array}{l}\text { R. v. Johnson } \\
\text { (G.) }\end{array}$ & 1994 & YK CA & x & x & Y \\
\hline 45 & 101 & R.v.R. (S.) & 1994 & NF SC & & & $\mathrm{N}$ \\
\hline 46 & 102 & R. v. Morin (I.) & 1993 & SK QB & x & & $\mathrm{Y}$ \\
\hline 47 & 103 & R.v. Cheekinew & 1993 & SK QB & & & $\mathrm{N}$ \\
\hline 48 & & R. v. Moses & 1992 & YK TC & x & & $\mathrm{Y}$ \\
\hline
\end{tabular}




\section{Appendix B}

\section{Whether the Judge Followed the Sentencing Circle's Recommendations: Cases Where Sentencing Circles were Held, by Case, Year, and Court}

\begin{tabular}{|c|c|c|c|c|c|}
\hline & $\begin{array}{l}\text { Hit \# In } \\
\text { Search }\end{array}$ & Case Name & Year & Court & $\begin{array}{c}\text { Recommendation } \\
\text { Followed }\end{array}$ \\
\hline 1 & 1 & R. v. Smarch & 2010 & YKTC & $\mathrm{U}^{*}$ \\
\hline 2 & 2 & R. v. Cooper & 2010 & Ont. CA & $\mathrm{N}$ \\
\hline 3 & 4 & R. v. Van Bibber & 2010 & YKTC & $\mathrm{Y}$ \\
\hline 4 & 6 & R. v. Langan & 2010 & SK PC & $\mathrm{N}$ \\
\hline 5 & 12 & R. v. Pauchay (II) & 2009 & SK PC & $\mathbf{N}$ \\
\hline 6 & 17 & R. v. Brooks & 2008 & NS PC & $\mathrm{Y}$ \\
\hline 7 & 19 & R. v. Stimson & 2008 & $A B P C$ & $\mathbf{U}$ \\
\hline 8 & 24 & R. v. MacKendrick & 2007 & $B C P C$ & $\mathbf{U}$ \\
\hline 9 & 25 & R. v. Elliot & 2006 & $\mathrm{AB}$ PC & $\mathbf{N}$ \\
\hline 10 & 27 & R. v. Poker & 2006 & NL TD & $\mathrm{N}$ \\
\hline 11 & 28 & R. v. Kahypeasewat & 2006 & SK PC & U \\
\hline 12 & 30 & $R$. v. James & 2006 & YKTC & $\mathrm{U}$ \\
\hline 13 & 32 & R. v. Craft & 2006 & YKTC & $\mathrm{Y}$ \\
\hline 14 & 33 & R. v. Desnomie & 2005 & SK CA & $\mathbf{U}$ \\
\hline 15 & 34 & R. v. Cappo & 2005 & SK CA & $\mathrm{Y}$ \\
\hline 16 & 36 & R. v. Anaquod & 2005 & SK CA & $\mathrm{U}$ \\
\hline 17 & 39 & R. v. J. (J.) & 2004 & NL CA & $\mathrm{Y}$ \\
\hline 18 & 46 & R. v. Morris** & 2004 & BC PC & $\mathrm{Y}$ \\
\hline
\end{tabular}

* U -Unknown: No deocription of recommondationo; thore was no information in case about what, if any, recommendatione were prosented following tho sontenoing circle. 


\begin{tabular}{|c|c|c|c|c|c|}
\hline 19 & 47 & R. v. Joyea & 2004 & SK CA & $\mathrm{U}$ \\
\hline 20 & 54 & R. v. $L .(B)$. & 2002 & $\mathrm{AB} \mathrm{CA}$ & $\mathrm{Y}$ \\
\hline 21 & 58 & $R$. v. $K(N . T)$. & 2001 & SK CA & $\mathrm{Y}$ \\
\hline 22 & 72 & R. v. Paul (D.) & 1998 & NB PC & $\mathrm{Y}$ \\
\hline 23 & 75 & R. v. Taylor & 1997 & SK CA & $\mathrm{N}$ \\
\hline 24 & 79 & R.v.C. (H.K.) & 1997 & SK CA & $\mathrm{U}^{* * *}$ \\
\hline 25 & 81 & R. v.R. (H. $)^{* * * *}$ & 1997 & $\mathrm{AB} P \mathrm{PC}$ & $\mathrm{N}$ \\
\hline 26 & 84 & R. v. McKay (R.W.) & 1997 & $\mathrm{AB} P C$ & $\mathrm{Y}$ \\
\hline 27 & 86 & R. U. McDonald (D.P.) & 1997 & SK CA & $\mathbf{U}$ \\
\hline 28 & 87 & R. v. Manyfingers (C.J.) & 1996 & $\mathrm{AB} P C$ & $\mathrm{Y}$ \\
\hline 29 & 89 & R. v. Nicholas (B.L.) & 1996 & NB PC & $\mathrm{Y}$ \\
\hline 30 & 90 & R. v. Severight (A.D.) & 1996 & SK CA & $\mathrm{U}$ \\
\hline 31 & 93 & R. v. Johns (J.C.) & 1995 & YK CA & $\mathbf{U}$ \\
\hline 32 & 95 & R. v. Taylor (W.B.) & 1995 & SK QB & $\mathrm{Y}$ \\
\hline 33 & 96 & R. v. John (R.C.) & 1995 & $\mathrm{AB} C \mathrm{CA}$ & $\mathrm{Y}$ \\
\hline 34 & 98 & R. v. Rope & 1994 & SK QB & $\mathrm{Y}$ \\
\hline 35 & 99 & R. v. Johnson (G.) & 1994 & YK CA & $\mathrm{Y}$ \\
\hline 36 & 102 & R. v. Morin (I.) & 1993 & SK QB & $\mathrm{Y}$ \\
\hline 37 & & R. v. Moses & 1992 & YK TC & $\mathrm{Y}$ \\
\hline
\end{tabular}

-* The judge left during the process.

*** The judge left during the process.

...* The Circle was conducted by Edmonton Native Youth Justice Committee ("ENYJC"), a group recognized by the Department of Justice. ENYCJ normally holds circles to assist in recommendations to the Edmonton Youth Court. However, in this case the defendant was charged as an adult because he was twenty-one years old at the time of the offence. 